\title{
Climate change impacts on fish reproduction are mediated at multiple levels of the brain-pituitary-gonad axis
}

\author{
Servili Arianna ${ }^{1,{ }^{*}}$, Canario Adelino V.M. ${ }^{2}$, Mouchel Olivier ${ }^{1}$, Muñoz-Cueto José Antonio ${ }^{3}$
}

1 Ifremer, Univ Brest, CNRS, IRD, LEMAR, F-29280 Plouzane, France

2 Comparative Endocrinology and Integrative Biology, Centre of Marine Sciences, Universidade do Algarve, Campus de Gambelas, 8005-139 Faro, Portugal

${ }^{3}$ Faculty of Marine and Environmental Sciences, INMAR, Department of Biology, University of Cádiz, Marine Campus of International Excellence (CEIMAR), Agrifood Campus of International Excellence (ceiA3) and European University of the Seas (SEA-EU), E11510-Puerto Real, Spain

* Corresponding author : Arianna Servili, email address : arianna.servili@ifremer.fr

\begin{abstract}
:
Anthropogenic emissions of carbon dioxide in the atmosphere have generated rapid variations in atmospheric composition which drives major climate changes. Climate change related effects include changes in physico-chemical proprieties of sea and freshwater, such as variations in water temperature, salinity, $\mathrm{pH} / \mathrm{PCO} 2$ and oxygen content, which can impact fish critical physiological functions including reproduction. In this context, the main aim of the present review is to discuss how climate change related effects (variation in water temperature and salinity, increases in duration and frequency of hypoxia events, water acidification) would impact reproduction by affecting the neuroendocrine axis (brain-pituitary-gonad axis).

Variations in temperature and photoperiod regimes are known to strongly affect sex differentiation and the timing and phenology of spawning period in several fish species. Temperature mainly acts at the level of gonad by interfering with steroidogenesis, (notably on gonadal aromatase activity) and gametogenesis. Temperature is also directly involved in the quality of released gametes and embryos development. Changes in salinity or water acidification are especially associated with reduction of sperm quality and reproductive output. Hypoxia events are able to interact with gonad steroidogenesis by acting on the steroids precursor cholesterol availability or directly on aromatase action, with an impact on the quality of gametes and reproductive success. Climate change related effects on water parameters likely influence also the reproductive behavior of fish. Although the precise mechanisms underlying the regulation of these effects are not always understood, in this review we discuss different hypothesis and propose future research perspectives.
\end{abstract}




\section{Graphical abstract}

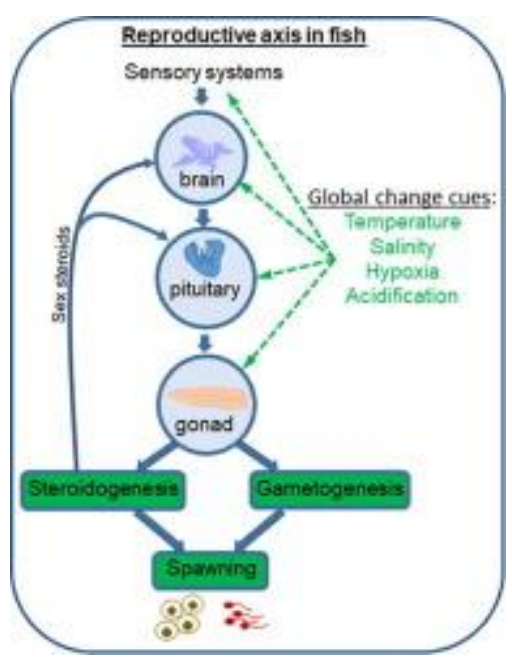

\section{Highlights}

- Changes in temperature, salinity, acidification and hypoxia impact reproductive behavior. Sex differentiation is affected by temperature and thermocycles. - Environmental cues act on steroidogenesis/gametogenesis affecting gamete quality. Global change related variations also affect spawning timing and phenology. Transgenerational studies show examples of acclimation and adaptation.

Keywords : climate change, fish reproduction, gonads, neuroendocrine regulation, environmental control, temperature. 


\section{General impacts of global change on fish}

Anthropogenic activities have generated cumulative emissions of carbon dioxide $\left(\mathrm{CO}_{2}\right)$ and other greenhouse gases since the industrial period causing notably an increase in atmospheric $\mathrm{CO}_{2}$ from 278 to 400 parts per million in the last 40 years (Bopp et al., 2013). This rapid surge of $\mathrm{CO}_{2}$ in the atmosphere has inevitably driven major environmental changes, including of aquatic ecosystems. The global ocean acts as a regulator of the global climate, through continuous exchanges with the atmosphere, and has absorbed 93\% of the Earth's additional heat since the 1970s, limiting atmospheric warming while slowly rising seawater temperature and sea level as a result of the melting of ice caps (Bopp et al., 2013; Church et al., 2013). The sea level is further increased by the collection of melting waters from glaciers, which will in turn alter the salinity, notably in polar regions. The ocean also stored $28 \%$ of anthropogenic $\mathrm{CO}_{2}$ emission since 1750 resulting in a drop of surface $\mathrm{pH}$, a process known as ocean acidification (Gattuso et al., 2015). A further consequence of the global warming is a reduction in dissolved oxygen $\left(\mathrm{O}_{2}\right)$ content of the world's oceans, because $\mathrm{O}_{2}$ is less soluble in warmer water and because of the enhanced stratification caused by the heating of surface waters, which in turn will reduce the $\mathrm{O}_{2}$ supply to the deep ocean (Keeling and Garcia, 2002; Matear et al., 2000; Plattner et al., 2016). Moreover, aquatic organisms increase $\mathrm{O}_{2}$ consumption in warmer water, further reducing $\mathrm{O}_{2}$ availability (Matear and Hirst, 2003). There are now large expanses of hypoxic waters and an increase in duration and frequency of hypoxia events is predicted (Keeling and Garcia, 2002; Matear et al., 2000; Plattner et al., 2016).

If the anthropogenic fossil carbonic emission continue along the current trajectory, as predicted by the Intergovernmental Panel on Climate Change (IPPC) scenario called 'business as usual' (Representative Concentration Pathways (RCP) 8.5 ), the ocean pH will decrease by $0.4 \mathrm{pH}$ units by 2100 (Meinshausen et al., 2011; Pörtner et al., 2014). Moreover, according to this emission scenario the globally averaged sea level will rise of $0.67 \mathrm{~m}$ (Church et al., 2013), the sea surface temperature will increase of $2.73{ }^{\circ} \mathrm{C}$ and the oxygen content will decrease by $3.48 \%$ (Bopp et al., 2013). Predictions for future conditions in marine systems are affected by the composition of seawater, which is largely constant if compared to freshwater, especially confined and small freshwater systems (Attar, 2013; 
Millero et al., 2006). Predictions and models describing future freshwater systems scenarios are scarce and imprecise. Climate change directly impacts freshwater ecosystems since alteration in thermal and precipitation regimes will change the flow dynamics (for instance more unstable flow regimes between floods and droughts) and increase the water temperature (Field et al., 2014; Füssel et al., 2012). In addition, the acid rainfall of anthropogenic origin will contribute to increase the acidification of the rivers and lakes (Carpenter et al., 2003).

All these changes in physical and chemical properties of aquatic ecosystems inevitably impact organisms' physiology and phenology, and ultimately the composition of communities and food webs.

Fishes live in water and therefore they are directly affected by the ongoing changes aquatic ecosystems. A key and energetically expensive process for species survival and evolution is sexual reproduction which in fish is largely dependent on specific environmental cues that trigger or modulate sexual maturation and breeding (Pankhurst and Porter, 2003). Environmental conditions are also crucial for the offspring survival (Cushing, 1969). Thus, the ongoing rapid environmental changes directly interfere with reproductive processes and may jeopardize breeding success and survival.

In temperate and cold regions, most fishes are seasonal breeders and the reproductive cycle is driven mainly by cyclic temperature and/or photoperiod (day-length), which control the timing of spawning to match with the optimal period for the survival of offspring (Bromage et al., 2001; Pörtner and Farrell, 2008). In tropical and subtropical regions, temperature and rainfall can trigger reproductive activity which can extend for long periods. Atypical temperature regimes can modify the timing and duration of the reproductive season and the amount and quality of reproductive output (Durant et al., 2007). In these regions and particularly in reef fishes, a major driver of reproductive activity is the lunar stage. The lunar cycle is likely perceived by the fish and used as a synchronizer of several physiological activities, at the daily or seasonal scale, including synchronous gonad development and spawning (Takemura et al., 2004).

While photoperiod at a place is not affected by climate change, many species of mainly marine fishes have undergone movements towards the poles because of warming temperatures (Verges et al., 2019). As a result, they are now being subjected to significant shifts in photoperiod reproductive periods with possible delays and shorter reproductive seasons could be therefore expected.

One of key roles of temperature is to modify molecular structures and the rate of biochemical reactions and physiological processes (Schulte et al., 2011). As a result, temperature can act on the 
neuro- and endocrine reproductive axis at different levels (Pankhurst and Thomas, 1998). For instance, warmer water can alter gonadotrophin releasing hormone (GnRH) secretion, gonadotrophin clearance and gonadal steroidogenesis in salmonids (Van Der Kraak and Pankhurst, 1997; Pankhurst and King, 2010; Wang et al., 2010). Furthermore, temperature can modify gonadal sex during critical time windows during early development (Diaz and Piferrer, 2015; Sandra and Norma, 2009; Strüssmann et al., 1997). For a recent review of the impact of climate change on sex differentiation in fish see Penman and Piferrer (2008), Piferrer (2013) and Piferrer et al. $(2005,2012)$.

Not so well studied is how ocean acidification may impact on fish reproduction. What is emerging is that increasing ocean partial pressure of $\mathrm{CO}_{2}\left(\mathrm{pCO}_{2}\right)$ may advance the timing of the breeding season and increase female reproductive output (i.e. egg production) in some fish species (Miller et al., 2013; Schade et al., 2014), although not in others (Forsgren et al., 2013; Welch and Munday, 2016), and may influence male reproductive behavior (Milazzo et al., 2016a). Whether these alterations are ecologically adaptive or not for the species remains to be determined. Most of these effects have been associated with alterations of internal fluid ion concentrations due to extra branchial ionic exchanges with the environment in an attempt to compensate internal $\mathrm{pH}$ in acidified water. This would lead to an impairment of the GABA signaling and actions as postulated by the GABA model (Nilsson et al., 2012; Regan et al., 2016). Olfactive performances are also impacted by ocean acidification as reported in several fish species and shark (Dixson et al., 2010, 2015: Green and Jutfelt, 2014; Jutfelt et al., 2013; Munday et al., 2016a,b). This could indirectly lead to at least some of the reproductive impairments observed in fish in acidified waters since a proper detection of chemical cues and sexual pheromones is critical for mating and other reproductive processes (Bett et al., 2016; Keller-Costa et al., 2015; Porteus et al., 2018). Furthermore, transcriptomic and proteomic evidences suggest that the circadian system is also affected by ocean acidification, which may drive downstream modifications in the control of neuroendocrine regulation of fish reproduction (Schunter et al., 2016; Servili et al., 2010, 2013). However, the precise molecular basis underlying the effects of ocean acidification on neurotransmission, olfaction and circadian system remains to be established.

Salinity is also known to impact breeding and to determine reproductive success in fishes (Helfman et al., 2009; Haddy and Pankhurst 2000; Lavett Smith, 1992); in particular, continuous reduction in salinity regime can affect reproductive and parental behavior (Hale, 2008; Lehtonen et al., 2016; St. Mary et al., 2001). Thus, changes in salinity can have an impact on fish spermatogenesis and testicular homeostasis, affecting gonadal cell proliferation and apoptosis (Cruz Vieira et al., 2019). It has been also shown that salinity levels can influenced some aspects of male nesting behaviour (i.e. nest entrance size) in marine fish (Lehtonen et al., 2016). 
At present, there is a scarcity of data on the effect of water deoxygenation on the reproductive performance of fish. What is known is that when fish cannot escape from hypoxic water, it will cope with this condition by i) improving oxygen delivery and transport and ii) by reducing energy demand and eventually iii) increasing energy supply by anaerobic metabolism (Abdel-Tawwab et al., 2019; $\mathrm{Wu}$, 2002). Prolonged hypoxia reduces fish growth and feeding which can indirectly affect reproduction. For example, hypoxia was found to reduce reproductive output by affecting both female and male gonadal development and gamete production (Lai et al., 2016b; Thomas and Rahman, 2009a, 2010; Wu et al., 2003). In this context, we aimed in the present review to report and discuss the up to date knowledge on the impacts of global change on reproduction in marine and freshwater fish, with a special focus, when possible, on the effects on the neuroendocrine regulation along the brain-pituitary-gonad axis.

\section{How brain-pituitary-gonad axis works in fish in present-day environmental conditions}

Fish reproduction has a considerable interest for both basic and applied research given the importance of this process for the maintenance of species, the high number of fish species (more than 25000 , representing a half of all living vertebrates), exhibiting very different reproductive tactics and strategies (gonochorism, hermaphroditism, parthenogenesis, external fertilisation, oviparity, ovoviviparity, viviparity), their key position in vertebrate phylogeny and the increasing importance of aquacultured fish as a food resource. The success of the reproductive process is dependent on the accurate integration of environmental cues and their transduction into a cascade of neurohormones and hormones driving reproduction. The purpose of this sequence of events is to ensure that reproduction occurs at the time of the day and the year most favourable for the survival of progeny.

The reproductive process of fish has a marked rhythmic character, regulated by cyclical environmental factors, particularly, photoperiod and temperature. In their natural habitats at temperate latitudes, fish are exposed to the daily and seasonal changes of the cycles of light and darkness (longer days in summer, shorter days in winter, and intermediate duration in spring and autumn) and to the progressive changes in water temperature, not only seasonally (warmer waters in summer, colder waters in winter, and intermediate temperatures in spring and autumn) but also along the day (higher temperatures during the day, lower temperatures during the night and early morning). These variations in the duration of daylight and in water temperature are periodic and repetitive from one year to another, and represent reliable signals that fish use to synchronize their 
physiological rhythms. In response to these cyclical variations, some species reproduce in particular seasons of the year and precise moments of the day (Falcón et al., 2010).

The success of reproduction requires that the individuals are synchronised with the variations of environmental factors but the synchronisation of internal processes among the reproductive partners is also essential to achieve the simultaneous maturation. The correct development of all these processes requires numerous and complex interactions that take place throughout the entire pineal-brain-pituitary-gonad axis (Falcón et al., 2010). For this purpose, the individuals are equipped with sensory systems and specific receptors that perceive the relevant environmental (photoperiod, temperature, $\mathrm{pH}$ ) and social (presence of reproductive partners and competitors, density of population, proportion of sexes, pheromones) stimuli. In fish, the pineal organ, a photosensory neural structure with neurosecretory capacity, plays a very important role in the perception of photoperiod and temperature information, and in the coding of this information into the form of nerve (neurotransmitters) and neuroendocrine (melatonin) signals that allow the numerous rhythmic processes of the individual (and particularly, the processes controlling reproduction) to be synchronised with the surrounding environment. To date numerous rhythms of melatonin production have been described in both freshwater and marine fish species (Bromage et al., 2001; Sánchez-Vázquez et al., 1997; Vera et al., 2007; Zachmann et al., 1992). In all of them, plasma melatonin levels rise during the night and fall during the day. These cyclical daily changes are the result of the expression and rhythmic activity of the enzyme arylalkylamine $\mathrm{N}$-acetyltransferase (AANAT), the key enzyme in the biosynthesis of melatonin (Ekström and Meissl, 1997; Falcón et al., 2007). But these melatonin rhythms not only provide information about the time of the day; in poikilotherms, this hormone also undergoes seasonal variations both in duration and amplitude, related to the duration of the night and the temperature of the water, respectively. Thus, some species, such as the goldfish (Carassius auratus) exhibit higher nocturnal levels of melatonin at high ambient temperatures than at low temperatures (ligo and Aida, 1995) and similar evidence has been obtained in salmon (Salmo salar) and sea bass (Dicentrarchus labrax), which have maximum values of nocturnal melatonin in the warm months (Randall et al., 1995; García-Allegue et al., 2001). In this way, melatonin can represent both a clock and a calendar for these species (Reiter, 1993, Saha et al., 2019).

The information provided by the pineal organ must reach, directly or indirectly, the neuroendocrine systems and modulate the synthesis of forebrain neurohormones that govern reproduction. Teleost fishes lack a median eminence and generally do not have the tetrapod portal system that places the hypothalamus in vascular contact with the pituitary (Zohar et al., 2010), although a remenacent of a hypothalamo-hypophysial portal system has been identified in a few teleost species (Baskaran and 
Sathyanesan, 1992; Golan et al., 2015; Sower, 2015). Therefore, these neurohormones reach more or less directly the cells of the adenohypophyseal anterior lobe, modulating the activity of the pituitary and triggering a series of endocrine cascades that lead to reproduction (Kah et al., 1993; Lethimonier et al. 2004; Zohar et al., 2010). The direct innervation of the teleost pituitary, together with the identification of a specific neurosecretory terminal in the neighbourhood of a particular hypophyseary cellular type, has enabled researchers to characterise those brain factors that may be involved in controlling the secretion of the pituitary hormones. In this way, the identification of terminals that secrete gonadotrophin-releasing hormone $(\mathrm{GnRH})$, dopamine, neuropeptide $\mathrm{Y}$ (NPY) and gamma-amino butyric acid (GABA) in close contact with gonadotrophic (LH and FSH) cells has provided an extremely useful neuroanatomical evidence for identifying the role and actions of these neurohormones and neurotransmitters on the secretion of gonadotrophins and on fish reproduction (Kah et al., 1987; 1989; 1992). Among these neurohormones, GnRH represents the main stimulatory factor, although other neuropeptides (NPY) and neurotransmitters (GABA, serotonin) have also been implicated in the stimulatory control of reproduction (Kah et al., 2007). In contrast, dopamine has been identified as the main inhibitory neurohormone in fish, and its actions in the reproductive axis have been evidenced in cyprinids, salmonids, eels and catfishes, among others (Dufour et al., 2010). This classic schema of neuroendocrine control of reproduction in fish has evolved in the last two decades with the identification of other stimulatory (kisspeptins, secretoneurin) and inhibitory (gonadotrophin-inhibitory hormone) factors (Zohar et al., 2010; Trudeau et al., 2012; Zmora et al., 2012; Muñoz-Cueto et al., 2017). These neurohormones stimulate or inhibit the synthesis and secretion of pituitary gonadotrophins (follicle-stimulating hormone or FSH, and luteinizing hormone or $\mathrm{LH}$ ) that, in turn, regulate the progression of gametogenesis and the synthesis of gonadal steroids, as well as other processes involved in reproduction (Zohar et al., 2010).

\section{How brain-pituitary-gonad axis could be impacted by global change.}

\subsection{Effects of global change on neurosensory system and reproductive behaviour.}

Temperature, acidification, hypoxia and change in pluviosity regimes are the main direct and indirect factors resulting from global climatic changes that are likely to influence fish reproductive behavior. In polar and mountain regions ice melting may also modify water salinity and composition. Because some fish will migrate to higher latitudes as the ocean waters warm, photoperiod and light quality will change. These different factors will be perceived by different sensory channels and elicit different neuroendocrine mediators. 
In teleost fish, thermoreceptors have been suggested to be located in the lateral line, a mechanosensory tissue continuously communicating with the central nervous system (Sullivan, 1954), but the consensus seems to be that they are scattered throughout the body probably innervated by spinal nerves (Fontaine, 1976). Mechanothermal nociceptors responding to extreme heat (above $20^{\circ} \mathrm{C}$ ), but not too cold, have been found in the head trigeminal nerve of rainbow trout, and their properties are closely linked to the behavior of rainbow trout in natural and high temperature stream pools (Ashley et al., 2007; Sneddon, 2003). TRPV1 is a cation-selective ion channel activated by high temperature and capsaicin functionally conserved throughout the vertebrates, which appear to act as molecular sensor of environmental heat in zebrafish (Gau et al., 2013) and possibly other fishes (Gracheva and Bagriantsev, 2015). However, overall the physiology of fish thermoreception has received little attention until now and information is lacking on how heat information is relayed to the neuroendocrine system and to reproduction.

Fish use chemical information to find their partners, establish and defend territories, for brood care and to synchronize reproductive cycles, among others (e.g. see reviews Keller-Costa et al., 2015; Stacey, 2014). Sensing of information is carried out by a sub-family of chemosensory G-protein coupled receptors of 7-transmembrane domains which are expressed in olfactory sensory neurons (OSN) located in the surface of olfactory epithelium (Lastein et al., 2014). Teleost fish chemosensory receptors belong broadly speaking to the same GPCR gene families as tetrapods despite the obvious anatomical differences and include the olfactory receptors (ORs), vomeronasal type 1 receptors (V1R or ORA), vomeronasal type 2 receptors (V2R or OlfC) and trace amine-associated receptors (TAARs) (Saraiva and Korsching, 2007). Fish pheromones seem to be detected by ORs, ORA and OlfC receptors (Silva and Antunes, 2017; Yabuki et al., 2016). There are three OSN populations - ciliated sensory neurons, microvillous sensory neurons and crypt cells. Prostaglandin F2 $\alpha$ (PGF2 $\alpha$ ) is detected by a high affinity OR in ciliated OSN and its mutation causes loss of attractive response to PGF2 $\alpha$ and of reproductive behaviour (Yabuki et al., 2016). OSN have projections to distinct regions of the olfactory bulb where they aggregate as glomeruli and form synapses to bulbar mitral cells. Axons of the mitral cells extend to the forebrain as olfactory tracts where they relay olfactory information to telencephalic centres. The medial olfactory tract projects largely to the ventral telencephalon and includes the projections of the GnRH neurons in the terminal that have been considered to encode preferentially pheromones (Becerra et al., 1994; Demski and Northcutt, 1983; Dulka, 1993; Forlano and Bass, 2011; Lastein et al., 2014; Peter, 1977; Satou et al., 1984; Sorensen et al., 1991). Interestingly, the terminal nerve seems to be a $\mathrm{CO}_{2}$ sensor mediating avoidance behavior to the gas (Koide et al., 2018). However, suggestions that the terminal nerve is specialized chemosensory system for pheromone detection has not been confirmed (arguments summarized by Stacey, 2014). 
Teleosts also have a direct connection from the olfactory bulb to the POA (anterior parvocellular) and to the posterior tuberal nucleus in the caudal diencephalon (Forlano and Bass, 2011). The responses to reproductive pheromone (at least in goldfish) are generally mediated by increases in LH although it may depend of social context (Stacey, 2014). In the goldfish, the pre-ovulatory steroid pheromone increases LH and milt, irrespective of fish being isolated or in groups, while the postovulatory prostaglandin pheromone only induces the same effects when in groups, suggesting, respectively, a simple neuroendocrine reflex and an indirect effect (Sorensen et al., 1989; Stacey, 2014; Zheng and Stacey, 1997). Downstream pituitary-gonad axis factors stimulated by LH are a series of steroids and prostaglandins, including pheromones and pheromone metabolites as shown, e.g., in goldfish and Mozambique tilapia (Huertas et al., 2014; Stacey, 2014). There are contradictory reports on the effect of $\mathrm{pH}$ and $\mathrm{CO}_{2}$ on olfaction. No effects of up to 2.5 times current $\mathrm{CO}_{2}$ levels were detected in three-spined stickleback reproductive behaviour (Sundin et al., 2017). However, at similar concentrations deleterious effects have been reported in juvenile European sea bass both at the olfactory system and central brain function with strong reduction in sensitivity towards aminoacids, alarm substance and bile acid at 2.5 times current levels of $\mathrm{CO}_{2}$ (Munday et al., 2014; Porteus et al., 2018). The effect could involve molecular changes with reduction of ligand-receptor affinity and downregulation of genes that are involved in synaptic plasticity. Ultimately, these changes modify $\gamma^{-}$ aminobutyric acid $A$ (GABAA) receptor function and behaviour, as suggested for coral fish and salmon (Nilsson et al., 2012; Williams et al., 2019). It is not yet known whether these changes influence reproduction but GABA mediates $\mathrm{GnRH}$ release and gonadotrophin secretion (Khan and Thomas, 1999; Mananos et al., 1999; Senthilkumaran et al., 2001) suggesting likelihood of possible effects. Reduced rates of paired spawning have been observed in ocellated wrasse (Symphodus ocellatus) (Milazzo et al., 2016b). In contrast, in two studies in the cinnamon anemonefish, Amphiprion melanopus (a coral reef fish), increased breeding activity was reported in one study and no effect in another (Miller et al., 2015; Miller et al., 2013). Overall it seems as if effects of $\mathrm{CO}_{2}$ on reproduction may depend on species or specific conditions.

\subsection{Effects of global change on sex determination and differentiation.}

Climate change pictures a scenario with milder, wetter and stormier winters and warmer and dryer summers. Although climate change effects will be stronger over land than over the ocean, these extreme weather events will also impact on water turbidity, salinity, flow and temperature. Increased runoff and flooding can alter salinity and water turbidity in coastal areas, thus modifying the penetration of light into the water column and affecting the characteristics of photic signals that entrain reproduction and other physiological processes. Variations in water flow can also influence vertical, upstream and downstream locomotor activity and migration of fish, many of them 
associated to reproductive process. Changes in water temperature affect particularly ectothermic animals such as fish because this environmental cue modulates many biochemical reactions and physiological processes, including reproduction.

Altogether, these alterations can determine undesirable effects on sex determination/differentiation, first maturity, gametogenesis, time of migration, spawning phenology and reproductive output (Jonsson and Jonsson, 2009; Wedekind and Küng, 2010; Blanco-Vives et al., 2011; Dorts et al., 2012; Villamizar et al., 2012).

Increased water temperature appears to represent the most detrimental factor of climate change, with the gonads as one the organs more damaged by high temperatures (Miranda et al., 2013). In fish, elevated temperature may have irreversible effects during sensitive periods of early development, affecting larval growth, the incidence of malformations and sex determination/differentiation, provoking functional masculinization (Strüssmann and Patiño, 1999; Piferrer et al., 2005). One of the effect of higher water temperatures seems to be mediated by the methylation of gonadal cyp19a1a gene promoter, which results in the inhibition of aromatase expression and masculinization of genotypic females (Navarro-Martín et al., 2011). In a recent study performed in developing sea bass it was shown that high temperature regimes, which have masculinizing effects in this species (Piferrer et al., 2005), decreased the expression of gonadotrophin-inhibitory hormone (gnih) and its receptor (gnihr) during the critical thermosensitive period (Paullada-Salmerón et al., 2017). GnIH has also been implicated in gonadal steroidogenesis in sea bass, decreasing testosterone and 11 ketotestosterone plasma levels (Paullada-Salmerón et al., 2016). Therefore, elevated temperature might modulate the sex differentiation process and induce masculinization through its action on gonadal steroid synthesis and/or release during early developmental stages by acting at different levels of the developing reproductive axis (e.g., gonad and brain).

In the wild, water temperature cycles not only seasonally but also daily, warming up after sunrise and cooling rapidly after sunset (Villamizar et al., 2012). Thermocycles may represent important entrainment factors even when daily light cycles are present, as reported for clock gene expression, circadian activity rhythms or circadian rhythms of hatching (Lahiri et al., 2005; López-Olmeda and Sánchez-Vázquez, 2009, 2011; Blanco-Vives et al., 2011; Villamizar et al., 2012). In juvenile sole, natural daily thermocycles increased estradiol levels and decreased 11 ketotestosterone and testosterone levels, advanced sex determination and affected sex differentiation by modifying the sex ratio (higher proportion of females) compared to inverted thermocycles or constant temperature (Blanco-Vives et al., 2011). According to this evidence, zebrafish larvae exposed to natural 
thermocycles also exhibited higher female-to-male ratio and ovarian aromatase expression, which could lead to an estrogen-dependent female differentiation (Villamizar et al., 2012). Increased water temperature associated to global warming can also affect daily thermocyles and, therefore, can disturb gonadal development and maturation.

There is increasing evidence that thermal effects on sex determination may be, at least partially, regulated by stress and mediated through the hypothalamic-pituitary-interrenal (HPI) axis (Pankhurst, 2016). Thus, pejerrey, medaka and Japanese flounder larvae reared under high temperatures regimes were masculinized and exhibited elevated whole body cortisol levels, being these masculinizing effects of elevated temperature reproduced by treatment with cortisol and/or prevented by cotreatment with the cortisol synthesis inhibitor metyrapone (Hattori et al., 2009; Hayashi et al., 2010; Yamaguchi et al., 2010).

\subsection{Effects of global change on steroidogenesis and gametogenesis affecting gamete quality and reproductive output.}

Seasonal reproduction and progression of gametogenesis is also under the control of temperature and other environmental cues, as it was shown in many fish species (Zanuy et al., 1986; Migaud et al., 2002, Lahnsteiner and Kletzl, 2012). Thus, it is evident that climate change related variation in water parameters can alter the quality of gametes in fish.

The quality of fish gametes is critical to assure viable reproductive output. It is defined as the ability to successfully fertilize (for sperm) or be fertilized (for egg) and consequently generate viable embryos (Bobe and Labbe, 2010; Reading et al., 2018). Gamete quality in fish is highly variable and is influenced by a range of endogenous and exogenous factors. The former includes the nutritional and energy status of the broodstock, while the latter mostly relies on social interactions and environmental factors. Nowadays, although the efforts of the last decade, the understanding of which external factors are involved and how they control the quality of fish gametes is not completely achieved. There is a series of quality estimators that are generally used in fish. It includes the size and morphology of unfertilized eggs (Bromage et al., 1994; Mansour et al., 2007), physicochemical parameters of ovarian fluid (as pH) (Aegerter and Jalabert, 2004; Fauvel et al., 1993; Lahnsteiner, 2000); sperm motility, membrane integrity, permeability and energy metabolism (Ciereszko and Dabrowski, 1994; Gallego and Asturiano; Labbe and Maisse, 2001; Muller et al., 2008; Zilli et al., 2004); fertilization rate and buoyancy of fertilized eggs (Kjørsvik et al., 1990; Sakai et al., 1985; Shields et al., 1997); embryonic survival and malformation at key steps of the development (eyed stage, hatching and yolk-sac resorption stage) (Bobe and Labbe, 2010; Bonnet et al., 2007). 
It is also noteworthy that certain environmental cues can directly impact the survival or the normal development of the embryo independently of the quality of the gametes produced by the breeders.

It is generally accepted that temperature and photoperiod can affect several quality estimators of both eggs and sperm in several marine and freshwater fish species. This is particularly true whether low or high temperatures occurs during vitellogenesis and spawning period. The main effect of variation (rise or decrease) in temperature regimes is a shift (advancement or delay) in spawning period (Bobe and Labbe, 2010; Miranda et al., 2013), which is often associated to reduced fecundity (in Atlantic halibut, (Brown et al., 2006); in rainbow trout, (Pankhurst et al., 1996; Pankhurst and Thomas, 1998)), fertility (in pejerrey, (Miranda et al., 2013); Atlantic cod,(Hutchings and Myers, 1994; Lahnsteiner and Kletzl, 2012) and Atlantic salmon,(King et al., 2003, 2007)), egg quality (in Atlantic halibut, (Brown et al., 2006); Atlantic salmon (King et al., 2003, 2007); rainbow trout,(Aegerter and Jalabert, 2004) and Arctic charr, (Gillet et al., 1996)) and in some case with lower embryo survival (in rainbow trout, (Pankhurst et al., 1996; Pankhurst and Thomas, 1998) and in common wollfish, (Tveiten et al., 2001)) and higher deformity rates (in rainbow trout, (Aegerter and Jalabert, 2004)).

The precise mechanism of action by which temperature regulates gamete quality is not very well understood. In several fall spawner species, when warming occurs during the pre-spawning period, the delayed ovulation is caused by a decrease in estradiol level. When warming treatment is applied during spawning phase, the delay or the complete loss of ovulation is associated to a disruption of 17,20ß-dihydroxy-4-pregnen-3-one (17,20ßP) synthesis (Gillet, 1991; Gillet et al., 2011; Jobling et al., 1995; King et al., 2003, 2007; Pankhurst et al., 1996; Pankhurst and Thomas, 1998). In spring spawners, when rising temperatures occur in the pre-spawning period an advanced spawning phase is observed due to an increase in estradiol levels. If warming take places during the spawning phase, a drop in estradiol concentration is observed (it is not known whether $17,20 \beta \mathrm{P}$ is also disrupted in spring spawners) (Hutchings and Myers, 1994; Miranda et al., 2013; Newman et al., 2010; Tveiten, 2008). As a result, the major effect of warming on female fish is a disruption of estrogen synthesis.

This disruption of ovarian estrogen production by high temperature is due to the inhibition of the expression and activity of gonadal aromatase (cyp19a1a) gene, which converts androgens to estrogen. The expression of aromatase gene is down-regulated by high temperature and it causes the inhibition of oocyte development (Anderson et al., 2012; Elisio et al., 2012; Lim et al., 2003; Watts et al., 2004). In vitro studies on the effects of increased temperature on isolated ovarian follicles suggest that ovarian function is directly disrupted at gonadal level independently of the brain-pituitary axis (Elisio et al., 2012; Watts et al., 2004). Accordingly, the inhibition of the expression and/or release of specific hormones at different levels of the reproductive brain-pituitary- 
gonad axis, observed in fish under warming conditions, would be the result of the feedback effect of the drop in plasma sex steroids level on the brain and pituitary. Disruption of estrogen levels would in turn inhibits the hepatic vitellogenin synthesis and consequently impacts eggs quality (Miranda et al., 2013). The reported effects of temperature at central level include the inhibition of the expression of hypophysiotropic gonadrotropin-releasing hormone by elevated thermal regimes in red seabream (Okuzawa et al., 2003), blue gourami (Levy et al., 2011) and pejerrey (Elisio et al., 2012), the inhibition of pituitary gonadotrophin ( $\mathrm{FSH}-\beta$ and/or $\mathrm{LH}-\beta$ ) synthesis by high temperatures in these species (Okuzawa et al., 2003; Soria et al., 2008; Levy et al., 2011; Elisio et al., 2012) and the reduction of circulating levels of $\mathrm{LH}$ by high temperature in female Arctic charr (Gillet and Breton, 2009). Although the role of stress in modulating temperature effects on reproduction in adult fish is not as clear as during early developmental stages, some evidences suggest that acute temperature changes might also inhibit reproduction through activation of the HPI axis (Pankhurst, 2016).

High temperature regime also affects oocyte osmoregulation and causes reduction in their content in phospholipids and free fatty acids (Lahnsteiner and Leitner, 2013). Deposition of lipids (triacylglycerols and phospholipids) during oocyte development is also affected in Arctic charr females held at high temperatures (Jobling et al., 1995).

Fewer evidences show the impact of temperature and photoperiod regimes on sperm quality. This impact can be indirect through the thermal acclimation of males during sperm production, or direct via the effect of activating water temperature on sperm performance upon release (Alavi and Cosson, 2005). Warming exposition during the pre-spawning phase may affect spermatogenesis with a decreased gonad testosterone and 11 ketotestosterone production as observed in some species (rainbow trout, (Manning and Kime, 1985)). It should be noted that 11 ketotestosterone is involved in proliferation of spermatogonia (Schulz et al., 2010). Therefore, androgen reduction could explain the reduction in spermatogonia and spermatocytes in pejerrey males exposed to high temperatures (Elisio et al., 2012). In this species, high temperatures also trigger the loss of mitotic capacity by the spermatogonia and germ cell loss at different development stages (larvae, juveniles, subadults, and adults) (Ito et al., 2008).

Cold acclimation of broodstock can affect the lipid composition in spermatozoa of rainbow trout (Labbé and Maisse, 1996). A recent study stressed out the distinct effect of changing temperatures on sperm quality over the reproductive period. Thus, early in the reproductive season, warm acclimation of male brown trouts reduced their sperm velocity, whereas later in the season, sperm quality was unaffected by acclimation temperature and thermal sensitivity was reduced (Fenkes et al., 2017). It has been hypothesized that the heat resistance of sperm cells in the freshwater teleost 
Labeo rohita is dependent of the thermosensitive ion channels TRPV (vanilloid transient receptor potential channels) that are responsible of $\mathrm{Ca}^{2+}$ influx and the subsequent activation of sperm movement (Majhi et al., 2013). In this case the variation of heat resistance of sperm during the reproductive period could be a result of the advance maturation of warm acclimated fish (Fenkes et al., 2017). However, the presence and function of TRPV channels in other fish species still need to be studied. The reduction in sperm quality of brown trout under increased temperature is also evidenced by the increased percentage of DNA damages in spermatozoa and the decreased seminal plasma peroxidase and lysozyme activities (Lahnsteiner and Leitner, 2013). Evidences obtained in trout and other salmonid species suggest that the negative effects of high temperature in spermiogenesis could be mediated by the alteration in testicular steroidogenesis and CAMP levels in spermatozoa (Manning and Kime, 1985; Cosson et al. 1995).

Changes in water salinity, especially when combined with $\mathrm{pH}$ variation, can also affect the quality of gametes and reproductive output in freshwater and marine fish. Notably, fertilization, hatching rate and egg development and viability are impacted by low salinity in marine fish (Allen et al., 2017; Nissling and Larsson, 2018; Nissling et al., 2002, 2006, 2017; Westin and Nissling, 1991). Alteration of sex steroid profiles were also described in relation to salinity treatments in both sexes of guppies (Moniruzzaman et al., 2018). To date, the precise mechanisms underlying such disruption have not been described. Increasing findings focus on the impact of salinity on sperm quality. By instance, spawning at low salinities affects duration, speed and number of motile spermatozoa in European flounder (Nissling and Larsson, 2018). High salinities interfered with the relationship between certain markers of testicular apoptosis, proliferation and DNA replication or development (caspase-3, PCNA and HSP70) in Nile tilapia, without altering plasma level of 11 ketotestosterone (Cruz Vieira et al., 2019). When salinity and also $\mathrm{pH}$ of the activating water vary, the sperm activation is directly impacted resulting in disruption of the duration of sperm motility and proportion of motile spermatozoa (Alavi and Cosson, 2006; Magnotti et al., 2018). It has been show that salinity and pH act on the osmolarity of the environmental water, which is a major factor regulating the different sperm motility parameters in fish as shown for example in sea bass, sea bream, Atlantic halibut, grey mullet and southern hake (Billard, 1978; Billard et al., 1993; Effer et al., 2013; Yeganeh et al., 2008). In fact, spermatozoa remain in a non-activated status in the testes and seminal plasma at isotonic conditions. When spermatozoa are released into the water the motility is activated by the hypo or hyperosmotic conditions for freshwater or marine species, respectively (Alavi and Cosson, 2006; Billard, 1986; Morisawa and Suzuki, 1980; Stoss, 1983). By instance, for marine species, the higher salinity of the seawater causes the release of water from the spermatozoa and the consequent increase of the internal concentration of certain ions (especially calcium) and the activation of 
motility (Boj et al., 2015; Cosson et al., 2008). Thus, inappropriate concentrations of salts, $\mathrm{pH}$ and osmolality can depolarize the cell membrane and disrupt flagellar motility of the spermatozoa (Morisawa and Suzuki, 1980; Morisawa et al., 1983; Vilchez et al., 2017). The reduced sperm motility may lead to low fertilization success (Cosson, 2004; Cosson et al., 1985; Stoss, 1983).

With the exception of the cited effects of $\mathrm{pH}$ on sperm motility, nowadays there is a lack of knowledge in the context of the water acidification about the effect of elevate $\mathrm{PCO}_{2}$ and low $\mathrm{pH}$ on the quality of gametes and offspring in fish. Nevertheless, during the last years we noticed a real increasing interest on this topic. However, the available findings are contradictory as they show opposite effects among species, exposure times and intensities of the acidification treatment. By instance, even when two close related coral damselfish species, as the Amphiprion percula and the Acanthochromis polyacanthus, are faced to elevated $\mathrm{PCO}_{2}$ (about $900 \mu \mathrm{atm}$ ) they may show opposite impacts. Reproductive output increased (in total number of eggs produced and number of eggs per clutch) in A. percula, while it decreases (in number of clutches) in A. polyacanthus in elevated $\mathrm{PCO}_{2}$ group compared to present-day $\mathrm{PCO}_{2}$ group (Welch and Munday, 2016). Egg survival and hatching rate was not impacted in $A$. percula, but they increased with elevated $\mathrm{PCO}_{2}$ in $A$. polyacanthus (Welch and Munday, 2016). Embryo size was not affected in both species (Welch and Munday, 2016). An increased reproductive output is also noted in acidified conditions in other species (Schade et al., 2014) including another coral fish (A. melanopus (Miller et al., 2013)), although a posterior study on the same species reported no effects of high $\mathrm{PCO}_{2}$ on reproductive output (Miller et al., 2015). Similarly, findings on the temperate species ocellated wrasse (Milazzo et al., 2016a) and the previous studies on two-spotted goby (Forsgren et al., 2013) submitted to acidified water did not show any differences in number of eggs laid. Once again, a second study of the same species, the two-spotted goby, suggests a stimulated reproductive output in high $\mathrm{CO}_{2}$ conditions in terms of numbers of eggs spawned but no effects on egg size. Hatched larvae were significantly smaller in acidified conditions likely revealing a trade-off between the number and size of eggs/offspring. This suggests a $\mathrm{CO}_{2}$ effect on parental provisioning related to the fact that females in high $\mathrm{CO}_{2}$ produced more eggs (Faria et al., 2018). Laboratory studies, currently undergoing in our laboratory, indicate that sea bass females under acidified conditions produce low quality eggs, as illustrated in figure 1. Further analyses are required to depict the molecular mechanisms underlying such effect.

It is generally accepted that embryonic and larval stages of fishes may be more vulnerable to decreasing environmental $\mathrm{pH}$ than adult stage due to their higher surface-to-volume ratio and lack of functional specialized mechanisms for acid-base regulation (Ishimatsu et al., 2008; Kikkawa et al., 2003). Nevertheless, to date contradictory results describe also the effects of elevated $\mathrm{PCO}_{2}$ and low $\mathrm{pH}$ on the early development of fish in terms of growth, malformation rates and physiological 
performances (recently review by (Vagner et al., 2019)). There is a need of long term studies in an extensive number of fish species exposed to comparable levels of $\mathrm{PCO}_{2}$ at similar life and reproductive stages in order to better understand the effect of water acidification on gamete quality and reproductive output.

Different hypothesis have been formulated on the mechanisms by which water acidification would affect reproductive output in fish. The first one concerns the already cited GABA model hypothesis by which the altered function of GABAA receptor under high $\mathrm{PCO}_{2}$ conditions would affect the release of reproductive hormone in the brain (mainly $\mathrm{GnRH}$ ) and pituitary (gonadotrophins) of fish (Nilsson et al., 2012). The role of GABA on reproductive hormones varies among fish species acting by stimulating or inhibiting the gametogenesis (Trudeau et al., 1993), which is consistent with the contradictory results obtained in the different species and studies. Detailed analysis of hormonal profiles in different fish species exposed to low $\mathrm{pH}$ is critical to test this hypothesis.

Another hypothesis that could explain the effects of rising $\mathrm{CO}_{2}$ on reproductive output would imply the alteration of the circadian rhythms systems in fish, which drive the modulation of reproductive axis by acting on the brain via the role of melatonin on GnRH expression (Servili et al., 2010, 2013). Circadian system has suggested to be regulated by ambient $\mathrm{CO}_{2}$ concentration as described by Schunter and collaborators (Schunter et al., 2016). Whether this effect could act directly at gonadal levels and on the production of gametes is not known. Studies on the transcriptomic and proteomic signatures of fish gonads sampled from fish acclimated under different $\mathrm{PCO}_{2} / \mathrm{pH}$ conditions are needed to solve this question.

Further climate change-related effects, such as hypoxia events, are likely to strongly affect the quality and amount of fish gamete and viability of the offspring. Both male and female gamete quality is disrupted by long-term hypoxic exposure in freshwater and marine fish species in both field and laboratory studies. Thus, similarly to the results obtained in a laboratory study (Thomas et al., 2007), the production of viable mature eggs and sperm is decreased in Atlantic croaker in the northern Gulf of Mexico hypoxic zone compared to reference areas (Thomas and Rahman, 2012; Thomas et al., 2015). Similar results have been reported in other teleost species (Cheek et al., 2009; Landry et al., 2007; Wu et al., 2003). In Atlantic croaker, the $19 \%$ of females sample in hypoxic sites show ovarian masculinization indicated by the presence of male germ cells at all stage in the developing ovaries (Thomas and Rahman, 2012). This gonad masculinization and the consequent biased sex ratio, also observed in zebrafish (Shang et al., 2006) exposed to hypoxia, is likely due to a sharp decrease in ovarian aromatase, enzyme that converts androgens into estrogens (Shang et al., 2006; Thomas and Rahman, 2012; Thomas et al., 2015). Aromatase activity is critical for the normal development and 
differentiation of teleost ovary (Guiguen et al., 1999, 2010). An impairment of estrogen signaling has been also suggested by the down regulation of the hepatic estrogen receptor alpha and the plasma level of vitellogenin, produced by the liver under estrogenic stimulation. Vitellogenin is required for the full growth of oocytes. In turn, the estrogen signaling disruption would also be the explanation of the reduction in number of mature oocytes in fish from hypoxic sites. Further evidence of impairment of steroidogenic pathway has also been provided by transcriptomic study of ovary of marine fish under hypoxic stress (Lai et al., 2016b). Notably, reproductive effects induced by hypoxia included the stimulation of progesterone synthesis, activation of internal genitalia development and inhibition of atresia of the reproductive tract. This disruption is driven by a modulation of reproductive activator (i.e. follicle stimulating hormone (FSH) and insulin-like growth factor 1 receptor (IGF1R)) and inhibitor (leukemia inhibitory factor (LIF)) factors (Lai et al., 2016b).

A recent pilot study proposed a further mechanism by which hypoxia can disrupt the sex steroid signaling in fish gonad. Interestingly, this study reports that cyclic hypoxia impacts plasma lipid dynamic in particular by depleting total cholesterol and high density lipoprotein (HDL) and rising triglycerides (TG) during the late phase of gonad development in both male and female goldfish (Bera et al., 2017). Authors suggest that the hypoxia-driven depletion of plasma cholesterol and HDL concentration can inhibit cholesterol availability for gonads. Because cholesterol is the precursor to all steroid hormones, such as estrogens, androgens, and corticosteroids (Scott, 1987) a reduction of cholesterol level will inevitably affect sex hormones profiles (Bera et al., 2017). Further studies on the role and environmental sensitivity of lipid dynamic on gamete quality is really necessary to better understand and predict the effects of climate change on the recruitment of fish species. A last level of regulation of the hypoxic effects on gamete quality in fish has been showed by Lai et al. (Lai et al., 2016a) studying female medakas. The authors have reported that hypoxia alters steroidogenesis (steroidogenic enzymes and hormones receptors) also through the action of a large number of miRNAs in the ovary (Lai et al., 2016a).

In addition, hypoxia can disrupt the final maturation (or maturational competence) of mature oocytes and sperm which is critical to produce viable gametes. Hence, the reduced maturational competence reported in Atlantic croaker under hypoxic condition was associated with a decrease of membrane progestin receptor alpha ( $\mathrm{mPR} \alpha$ ) expression level in gametes (Thomas and Rahman, 2009b; Thomas et al., 2015). The stimulation of this steroid receptor (mPRa) is regulated via LH dependent production of the 17,20,21-trihydroxy-4-pregnen-3-one (20ß-S) on the cell surface of oocyte and sperm (Tubbs and Thomas, 2009; Zhu et al., 2003). Thus, hypoxic stress impacts the nongenomic progestin signaling of fish gamete, leading to impairment of reproduction. Although the well-established role of the nuclear progesterone receptor (nPR) in ovulation of fish (Hagiwara et al., 
2014; Tang et al., 2016; Zhu et al., 2015), by the mediation of LH (through the classical genomic progestin pathway), to our knowledge the influences of environmental factors on such regulation are not known.

The impact of a hypoxic exposure on early life stage is fish includes the reduced survival and growth rate at hatching, delayed development and increase of malformation in embryos (Del Rio et al., 2019; Dudley and Eipper, 1975; Marks et al., 2012; R. Carlson and E. Siefert, 2011; Shang and Wu, 2004) at embryonic stage. Hatching is a very energetically costly process for fish due to the increased movement and oxygen consumption (Hamor and Garside, 1976; Ninness et al., 2011). In a context of hypoxic exposure, the hatching embryo with limited ability to anaerobic metabolism, could not be able to face the increased aerobic energy demand (Polymeropoulos et al., 2015).

Also the reduced growth and delayed development could be associated to hypoxia compensatory responses where metabolic demand is adjusted to match oxygen and energy supply (Rombough, 1988). Interestingly, hypoxia can have two opposite effects on time to hatch, depending of the rearing temperature. Hatching time can be delayed by hypoxia, since overall development is delayed, or advanced, as metabolic rate increases with developmental stages (Rombough, 1988). When oxygen availability becomes limiting, hypoxia can provoke a premature hatching, since low oxygen is natural signal to hatch in some fish embryo (Czerkies et al., 2001). Delayed embryonic development is also associated to disruption in apoptotic signaling and in sex hormone balance in embryo which could impact the sexual development of pubertal fish (Shang and Wu, 2004).

Altogether, the reported data clearly show that hypoxia acts as an endocrine disruptor by acting on the sex steroid regulation of gonadal functions with teratogen effects in embryos of several fish species. Evidences also point to inhibitory effects on reproduction at central level caused by deoxygenated water (Pankhurst, 2016). For instance, hypoxia downregulates the expression of GnRH in the brain and FSH $\beta$ and LH $\beta$ in the pituitary in zebrafish (Lu et al., 2014) and in Atlantic croaker, it inhibits brain $\mathrm{GnRH}$ gene expression associated to a decrease in serotonin hypothalamic levels (Thomas et al., 2007).

A schematic representation of the main effects of climate change related environmental cues on gamete quality is illustrated in figure 2 .

\section{Evidence for adaptation and acclimation}


When migration is not possible, the response of organisms to rapid environmental changes are within-generation phenotypic plasticity, transgenerational plasticity and genetic adaptation (Bonduriansky et al., 2012; Hoffmann and Sgro, 2011; Munday et al., 2013; Salinas et al., 2013; Shama et al., 2014). The phenotypic plasticity, occurring within one generation, is defined as the way of an organism (one genotype) to respond to an environmental cue with a change in the phenotype, by varying form, state, movement or rate of activity (West-Eberhard, 2005). Transgenerational plasticity and genetic adaptation occur along generations, being the transgenerational plasticity a type of non-genetically inheritance in which the environment experienced by the parents influences the offspring reaction norms (the phenotypes expressed in response to different environments by the same genotype) (Bonduriansky et al., 2012; Salinas et al., 2013) and the genetic adaptation a process by which the environmental input drives the genetic selection over generations (Hoffmann and Sgro, 2011).

It's important to remind that the predicted scenarios for climate change reflect changes in environmental cues that will be reach over several generations, likely allowing transgenerational plasticity to occur. Yet, relatively little is known about the capacity for plasticity of reproductive processes to changing environments over multiple generations (transgenerational plasticity).

The large majority of studies aiming to predict the effects of climate change on reproduction of fish focused so far exclusively on the acclimation ability (phenotypic plasticity) of a species face to one or a combination of stressful environmental cues. Although, understanding the transgenerational plasticity of fish species to the different climate change related factors (warming, water acidification, hypoxia and low salinity) is essential to be able to verisimilarly predict the real impact of climate change on fish populations. Since transgenerational plasticity is a fast and often adaptive phenotypic response mechanism, it can buffer populations against environments experienced by the previous generations and provide time for genetic adaptation to catch up (Bonduriansky et al., 2012; Chevin et al., 2010; Marshall and Uller, 2007; Räsänen and Kruuk, 2007).

To date, transgenerational plasticity for reproductive related traits has been reported in few fish species when submitted to increasing warmer temperatures through generations (Donelson et al., 2014, 2016; Shama and Wegner, 2014). By instance, successive studies on the coral reef damselfish, Acthochromis ployacantus, showed that, despite the fact this species has little capacity for reversible acclimation as adults (Donelson et al., 2010), acclimation of some reproductive traits is possible when fish developed in ocean temperatures $1.5^{\circ} \mathrm{C}$ greater than present-day for their entire life (within generation acclimation). This was not the case when individuals experienced $+3.0^{\circ} \mathrm{C}$ warmer conditions, suggesting limitations to thermal acclimation (phenotypic plasticity) (Donelson et al., 
2014). However, when examined two generations encountering gradual increase in temperature, $+1.5^{\circ} \mathrm{C}$ in the first generation and then $+3.0^{\circ} \mathrm{C}$ in the second generation, authors observed full restoration of the thermally affected reproductive and offspring traits, and greater plasticity than that to fish that experienced the same increase in one generation (transgenerational plasticity) (Donelson et al., 2014, 2016). By evaluating expression levels of reproduction related genes in brain and gonad, the authors were able to identify a role for testicular gonadotrophin receptors (LHCGRr and FSHRr) in reproductive plasticity in coral reef damselfish (Veilleux et al., 2018). Of course the acclimation to warmer temperature can incur some cost or reveal trade-offs with other fitnessrelated traits (Angilletta et al., 2003). As a result, transgenerational effects are dependent of the extent of thermal increase and also of the life stage in which the warming occurs (Donelson et al., 2016; Meier et al., 2014; Shama and Wegner, 2014).

Parental and grandparental exposure to deoxygenated water also influences reproductive performance of offspring. Thus, using marine medaka as a model species, recent experimental evidence indicates that hypoxia can cause transgenerational reproductive impairment in both sexes due to heritable epigenetic regulations (Lai et al., 2018, 2019; Wang et al., 2016). Hence, males of F1 and F2 progenies, never exposed to hypoxia, suffer delayed gonad development associated to reduction in sperm amount and motility, when grandparents developed under hypoxic condition (Wang et al., 2016). This means that hypoxia triggers epigenetic alterations, such as variation in DNA methylation pattern of sperm, and regulates expression of genes and proteins related to spermatogenesis and gene silencing (Wang et al., 2016). The transgenerational effects of hypoxia on testicular function of medaka have also been associated to an involvement of the brain. Comparative transcriptomic analyses have shown that changes in gene clusters and signaling pathways in the central nervous system are associated to transgenerational effects of hypoxia exposure on testicular function (notably the alteration of morphology of the epididymis and the seminal vesicle and degeneration of the seminiferous tubule) (Lai et al., 2018). This is in line with the well documented concept by which the suitable cross-talk between brain and testes is crucial for male fertility in vertebrates (Bruysters et al., 2008; Piomboni et al., 2014). Similarly, F2 medaka females, never exposed to hypoxia, retain the same reproductive impairment that expressed F0 fish under hypoxia (Lai et al., 2019). Such impairments include follicle atresia and retarded oocyte development and were related with modification of DNA methylation and expression profiles of gene clusters associated with cell cycle arrest and apoptosis (Lai et al., 2019). Thus, hypoxia cause transgenerational disruption in male and female germ lines of medaka trough different mechanism and phenotypic changes. Apart from DNA methylation, another mechanism of epigenetic regulations, i.e. miRNAs, is shown to be involved in the modulation of apoptosis and steroidogenesis in gonads of 
medaka in response to hypoxia (Lai et al., 2016a; Tse et al., 2015). As a result, the epigenetic changes and transgenerational reproductive impairments revealed so far suggest that hypoxia may cause a much more significant and long-term impact to aquatic animals than presently perceived. Although, we don't know so far whether offspring of parent and grandparent submitted to gradual increasing hypoxia, as it will likely occur in a context of the climate change prediction, could develop any sort of transgenerational plasticity to at least some of the reproductive traits.

To our knowledge, the transgenerational plasticity of reproductive traits has never been evaluated in fish in response to water acidification or low salinity, although experimental evidences suggest high potential for adaptive transgenerational acclimation in fish, at least under acidification condition, when considering other physiological endpoints (Miller et al., 2012; Munday et al., 2012; Vagner et al., 2019). Definitely, knowing the plasticity capacity of the reproductive processes and the underling mechanisms over generations are critical to understand and predict the persistence of fish species facing the predicted climate change scenarios.

Obviously, researchers should also take into account the genetic adaptation capacity of animals in order to predict their likely future persistence. In mammals has been described the strong influence of parental genotype on fertility, fecundity and oocyte quality. In fish the contribution of broodstock genetics on gamete quality is poorly documented (Bobe and Labbe, 2010). One example is the study of Stoddard et al., 2005 when the differential fertility in female rainbow trouts was related to genetic differences (Stoddard et al., 2005). Also estimators of sperm quality, like sperm swimming behavior, have been associated to genetic features in fish (Borowsky et al., 2019). Nevertheless, in fish the genetic contribution of parental genomes on gamete quality is difficult to assess since the zygotic transcription begins at a late stage of the embryonic development (during mid-blastula transition). Until then, embryonic development is driven by the maternal supplies of mRNA and proteins, which are potentially sensitive to variation in environmental cues and thus to climate change predicted scenarios.

To our knowledge, how the genotype evolution over generations will drive the reproductive performance and success in fish in response to climate change remain poorly documented (but see (Hoffmann and Sgro, 2011; Vincenzi et al., 2017)) except for a pioneer research in salmonids (Carlson and Seamons, 2008).

\section{General perspectives.}


Global climate change related effects of variations in water temperature, $\mathrm{PCO}_{2} / \mathrm{pH}$, oxygen content and salinity can impact the neuroendocrine control of reproduction in fish by acting at multiple levels of the brain-pituitary-gonad axis. Thus, global change is likely affecting the sexual maturation, reproductive behavior, gametogenesis, spawning and reproductive output. All the cited climate change related factors seem to affect steroidogenesis. It is worth mentioning that steroidogenic pathways are complex series of enzymatic reactions, where the product of one reaction can be the substrate of several enzymes, with final effect on levels of different steroid hormones. Thus, in order to understand the real impact of one factor on steroidogenesis, it is critical to consider the plasma levels of a wide range of steroids. Unfortunately, to date most study are limited to measure few steroids level and the whole picture is missing.

It is also important to note that the effects of climate change are not limited to breeders and gametes, but they also have direct consequences on their progeny, in particular at the level of the growth. By instance thermal embryonic history, potentially impacted by global warming, will influence growth and fitness of larvae and juveniles (Alami-Durante et al., 2007).

Most of laboratory and field studies have reported negative impacts of global change on reproductive performance on different fish species. Although, some fish show stimulation of reproduction with increasing fertility under acidified water, which could appear a beneficial adaptive response. However, we need to keep in mind that most research has considered the effects of only one or few environmental stressor(s) at the time, despite the fact that in nature animals will face the predicted levels of warming and acidification, sometimes associated with a decrease in oxygen availability and low salinity at once. This is particularly true for animals or life stages with limited capacity for active swimming. In this context the need of long term multi stress experiments is evident. In addition, in this review we focus on the direct effects of global change on the reproductive axis of fish. Nevertheless, we are aware of the indirect impacts of unfavorable environmental conditions on fish reproduction. They includes the effects of environmental factors on other hormonal systems, like the thyroid and stress axes, with evident consequences on the endocrine control of reproduction in fish (Eales and Brown, 1993; Eales et al., 1982; Lee et al., 2014; Wingfield and Sapolsky, 2003). Most of studies reveal inhibitory action of stress on fish reproduction, although in some conditions the increase of corticosteroid level may has stimulatory effects of reproductive processes (Milla et al., 2009). As a result, in this case climate change may play a paradoxical stimulatory role for reproduction (Pankhurst, 2016).

Furthermore, the energetic cost of compensative physiological response to stressing environment could have energetic consequence over long time scale that must hide trade-offs on reproductive or 
other physiological functions such as growth or development. Only long-term studies on the entire life cycle of fish species, followed by a complete phenotypic characterization of breeders and offspring will be able to properly assess this issue.

Finally, climate interactions with a species can be mediated through direct effects on key prey species, which change the composition and dynamic coupling of food webs. Thus, predictions of impact of climate change for fish must consider i) population level changes, trough variations of population species compositions and relative abundances and, finally, ii) ecosystem-level changes in productivity and food web interactions (Portner and Peck, 2010).

Declarations of interest: The authors declare no conflict of interest.

Funding: Funded by: a grant from the Spanish Ministry of Science, Innovation and Universities (AGL2017-82582-C3-1-R) to JAMC; by LabexMer (ANR-10-LABX-0019) OASYS project to AS; by the Ministry of Ecological and Solidarity Transition and operated by the Foundation for Biodiversity Research (FRB), (Ocean Acidification Program, PACIO project); by the FITNESS project (Deutsche Forschungemeinschaft, PE 1157/8-1).

\section{References}

Abdel-Tawwab, M., Monier, M.N., Hoseinifar, S.H., Faggio, C., 2019. Fish response to hypoxia stress: growth, physiological, and immunological biomarkers. Fish Physiol Biochem. doi: 10.1007/s10695-019-00614-9.

Aegerter, S., Jalabert, B., 2004. Effects of post-ovulatory oocyte ageing and temperature on egg quality and on the occurrence of triploid fry in rainbow trout, Oncorhynchus mykiss. Aquaculture (Amsterdam, Netherlands). 231, 59-71. doi: 10.1016/j.aquaculture.2003.08.019.

Alami-Durante, H., Olive, N., Rouel, M. 2007. Early thermal history significantly affects the seasonal hyperplastic process occurring in the myotomal white muscle of Dicentrarchus labrax juvenile. Cell and tissue research. 327:553-70.

Alavi, S.M., Cosson, J., 2005. Sperm motility in fishes. I. Effects of temperature and pH: a review. Cell Biol Int. 29, 101-110. doi: 10.1016/j.cellbi.2004.11.021.

Alavi, S.M., Cosson, J., 2006. Sperm motility in fishes. (II) Effects of ions and osmolality: a review. Cell Biol Int. 30, 1-14. doi: 10.1016/j.cellbi.2005.06.004.

Allen, J., Schrage, K., Foo, S., Watson, S.-A., Byrne, M., 2017. The Effects of Salinity and pH on Fertilization, Early Development, and Hatching in the Crown-of-Thorns Seastar. Diversity, 9, 13; doi: $10.3390 / \mathrm{d} 9010013$

Anderson, K., Swanson, P., Pankhurst, N., King, H., Elizur, A., 2012. Effect of thermal challenge on plasma gonadotropin levels and ovarian steroidogenesis in female maiden and repeat spawning Tasmanian Atlantic salmon (Salmo salar). Aquaculture. 334-337, 205-212. doi: 10.1016/j.aquaculture.2011.12.026. 
Angilletta, M.J., Wilson, R.S., Navas, C.A., James, R.S., 2003. Tradeoffs and the evolution of thermal reaction norms. Trends in Ecology \& Evolution. 18, 234-240. doi: 10.1016/S0169-5347(03)000879.

Ashley, P.J., Sneddon, L.U., Mccrohan, C.R., 2007. Nociception in fish: stimulus-response properties of receptors on the head of trout Oncorhynchus mykiss. Brain Research. 1166, 47-54. doi: 10.1016/j.brainres.2007.07.011.

Attar, A., 2013. Global environment: water, air and geochemical cycles. International Journal of Environmental Studies. 70, 155-156. doi: 10.1080/00207233.2012.753739.

Baskaran, G., Sathyanesan, A.G., 1992. Tetrapod-like hypothalamo-hypophysial portal system in the teleost Megalops cyprinoides (Broussonet). General and Comparative Endocrinology. 86, 211-219. doi: 10.1016/0016-6480(92)90104-R.

Becerra, M., Manso, M.J., Rodriguez-Moldes, I., Anadon, R., 1994. Primary olfactory fibres project to the ventral telencephalon and preoptic region in trout (Salmo trutta): a developmental immunocytochemical study. J Comp Neurol. 342, 131-143. doi: 10.1002/cne.903420112.

Bera, A., Sawant, P.B., Dasgupta, S., Chadha, N.K., Sawant, B.T., Pal, A.K., 2017. Diel cyclic hypoxia alters plasma lipid dynamics and impairs reproduction in goldfish (Carassius auratus). Fish Physiol Biochem. 43, 1677-1688. doi: 10.1007/s10695-017-0401-0.

Bett, N.N., Hinch, S.G., Yun, S.S., 2016. Behavioural responses of Pacific salmon to chemical disturbance cues during the spawning migration. Behav Processes. 132, 76-84. doi: 10.1016/j.beproc.2016.10.001.

Billard, R., 1978. Changes in structure and fertilizing ability of marine and preshwater fish spermatozoa diluted in media of various salinities. Aquaculture. 14, 187-198. doi: 10.1016/00448486(78)90094-7.

Billard, R., 1986. Spermatogenesis and spermatology of some teleost fish species. Reprod. Nutr. Dévelop. 26, 877-920.

Billard, R., Cosson, J., Crim, L.W., 1993. Motility of fresh and aged halibut sperm. Aquat. Living Resour. 6, 67-75.

Blanco-Vives, B., Vera, L.M., Ramos, J., Bayarri, M.J., Mañanós, E, Sánchez-Vázquez FJ. 2011. Exposure of larvae to daily thermocycles affects gonad development, sex ratio, and sexual steroids in Solea senegalensis, kaup. J Exp Zool A Ecol Genet Physiol. 315(3): 162-169.

Bobe, J., Labbe, C., 2010. Egg and sperm quality in fish. Gen Comp Endocrinol. 165, 535-548. doi: 10.1016/j.ygcen.2009.02.011.

Boj, M., Chauvigne, F., Cerda, J., 2015. Coordinated Action of Aquaporins Regulates Sperm Motility in a Marine Teleost. Biol Reprod. 93, 40. doi: 10.1095/biolreprod.115.131524.

Bonduriansky, R., Crean, A.J., Day, T., 2012. The implications of nongenetic inheritance for evolution in changing environments. Evolutionary Applications. 5, 192-201. doi: 10.1111/j.17524571.2011.00213.x.

Bonnet, E., Fostier, A., Bobe, J., 2007. Characterization of rainbow trout egg quality: a case study using four different breeding protocols, with emphasis on the incidence of embryonic malformations. Theriogenology. 67, 786-794. doi: 10.1016/j.theriogenology.2006.10.008.

Bopp, L., Resplandy, L., Orr, J.C., Doney, S.C., Dunne, J.P., Gehlen, M., Halloran, P., Heinze, C., Ilyina, T., Séférian, R., Tjiputra, J., Vichi, M., 2013. Multiple stressors of ocean ecosystems in the 21st century: projections with CMIP5 models. Biogeosciences. 10, 6225-6245. doi: 10.5194/bg-106225-2013. 
Borowsky, R., Luk, A., Kim, R.S., 2019. Sperm swimming behaviors are correlated with sperm haploid genetic variability in the Mexican tetra, Astyanax mexicanus. PLoS One. 14, e0218538. doi: 10.1371/journal.pone.0218538.

Bromage, N., Bruce, M., Basavaraja, N., Rana, K., Shields, R., Young, C., Dye, J., Smith, P., Gillespie, M., Gamble, J., 1994. Egg Quality Determinants in Finfish The Role of Overripening with Special Reference to the Timing of Stripping in the Atlantic Halibut Hippoglossus hippoglossus. Journal of the World Aquaculture Society. 25, 13-21. doi: 10.1111/j.1749-7345.1994.tb00799.x.

Bromage, N., Porter, M., Randall, C., 2001. The environmental regulation of maturation in farmed finfish with special reference to the role of photoperiod and melatonin. Aquaculture. 197: 63-98.

Brown, N.P., Shields, R.J., Bromage, N.R., 2006. The influence of water temperature on spawning patterns and egg quality in the Atlantic halibut (Hippoglossus hippoglossus L.). Aquaculture. 261, 993-1002. doi: 10.1016/j.aquaculture.2006.08.025.

Bruysters, M., Christin-Maitre, S., Verhoef-Post, M., Sultan, C., Auger, J., Faugeron, I., Larue, L., Lumbroso, S., Themmen, A.P., Bouchard, P., 2008. A new LH receptor splice mutation responsible for male hypogonadism with subnormal sperm production in the propositus, and infertility with regular cycles in an affected sister. Hum Reprod. 23, 1917-1923. doi: 10.1093/humrep/den180.

Carlson, A. R, Siefert, R.E., 2011. Effects of Reduced Oxygen on the Embryos and Larvae of Lake Trout (Salvelinus namaycush) and Largemouth Bass (Micropterus salmoides). Journal of the Fisheries Research Board of Canada. 31. 1393-1396. doi: 10.1139/f74-165.

Carlson, S.M., Seamons, T.R., 2008. A review of quantitative genetic components of fitness in salmonids: implications for adaptation to future change. Evol Appl. 1, 222-238. doi: 10.1111/j.1752-4571.2008.00025.x.

Carpenter, S., G. Fisher, S., Grimm, N., F. Kitchell, J., 2003. Global Change and Freshwater Ecosystems. Annual Review of Ecology and Systematics. 23. 119-139. doi: 10.1146/annurev.es.23.110192.001003.

Cheek, A.O., Landry, C.A., Steele, S.L., Manning, S., 2009. Diel hypoxia in marsh creeks impairs the reproductive capacity of estuarine fish populations. Marine Ecology Progress Series. 392, 211-221. doi: $10.3354 /$ meps08182.

Chevin, L.-M., Lande, R., Mace, G.M., 2010. Adaptation, Plasticity, and Extinction in a Changing Environment: Towards a Predictive Theory. PLOS Biology. 8, e1000357. doi: 10.1371/journal.pbio.1000357.

Church, J.A., Monselesan, D., Gregory, J.M., Marzeion, B., 2013. Evaluating the ability of process based models to project sea-level change. Environmental Research Letters. 8, 014051. doi: 10.1088/1748-9326/8/1/014051.

Ciereszko, A., Dabrowski, K., 1994. Relationship between biochemical constituents of fish semen and fertility: the effect of short-term storage. Fish Physiol Biochem. 12, 357-367. doi: 10.1007/bf00004300.

Cosson, M.P., Cosson, J., Andre, F., Billard, R. 1995. cAMP/ATP-dependence of movement in intact and demembranated trout spermatozoa. Cell Mot Cytoskel 31:159-176.

Cosson, J., 2004. The Ionic and Osmotic Factors Controlling Motility of Fish Spermatozoa. Aquaculture International. 12, 69-85. doi: 10.1023/B:AQUI.0000017189.44263.bc.

Cosson, J., Groison, A.L., Suquet, M., Fauvel, C., Dreanno, C., Billard, R., 2008. Marine fish spermatozoa: racing ephemeral swimmers. Reproduction. 136, 277-294. doi: 10.1530/rep-070522. 
Cosson, M.-P., Billard, R., Gatti, J.L., Christen, R., 1985. Rapid and quantitative assessment of trout spermatozoa motility using stroboscopy. Aquaculture. 46, 71-75. doi: 10.1016/00448486(85)90178-4.

Cruz Vieira, A.B., Weber, A.A., Ribeiro, Y.M., Luz, R.K., Bazzoli, N., Rizzo, E., 2019. Influence of salinity on spermatogenesis in adult Nile tilapia (Oreochromis niloticus) testis. Theriogenology. 131, 1-8. doi: 10.1016/j.theriogenology.2019.03.013.

Cushing, D.H., 1969. The Regularity of the Spawning Season of Some Fishes. ICES Journal of Marine Science. 33, 81-92. doi: 10.1093/icesjms/33.1.81.

Czerkies, P., Brzuzan, P., Kordalski, K., Luczynski, M., 2001. Critical partial pressures of oxygen causing precocious hatching in Coregonus lavaretus and C. albula embryos. Aquaculture. 196, 151-158. doi: 10.1016/S0044-8486(00)00545-7.

Del Rio, A.M., Davis, B.E., Fangue, N.A., Todgham, A.E., 2019. Combined effects of warming and hypoxia on early life stage Chinook salmon physiology and development. Conserv Physiol. 7 , coy078. doi: 10.1093/conphys/coy078.

Demski, L.S., Northcutt, R.G., 1983. The terminal nerve: a new chemosensory system in vertebrates? Science. 220, 435-437. doi: 10.1126/science.6836287.

Diaz, N., Piferrer, F., 2015. Lasting effects of early exposure to temperature on the gonadal transcriptome at the time of sex differentiation in the European sea bass, a fish with mixed genetic and environmental sex determination. BMC Genomics. 16, 679. doi: 10.1186/s12864-0151862-0.

Dixson, D.L., Jennings, A.R., Atema, J., Munday, P.L., 2015. Odor tracking in sharks is reduced under future ocean acidification conditions. Global Change Biology. 21, 1454-1462. doi: 10.1111/gcb.12678.

Dixson, D.L., Munday, P.L., Jones, G.P., 2010. Ocean acidification disrupts the innate ability of fish to detect predator olfactory cues. Ecology Letters. 13, 68-75. doi: 10.1111/j.14610248.2009.01400.x.

Donelson, J., L. Munday, P., Mccormick, M., Pankhurst, N., Pankhurst, P., 2010. Effects of elevated water temperature and food on the reproductive performance of a coral reef fish. Marine Ecology Progress Series. 401. doi: 10.3354/meps08366.

Donelson, J.M., Mccormick, M.I., Booth, D.J., Munday, P.L., 2014. Reproductive acclimation to increased water temperature in a tropical reef fish. PLoS One. 9, e97223. doi: 10.1371/journal.pone.0097223.

Donelson, J.M., Wong, M., Booth, D.J., Munday, P.L., 2016. Transgenerational plasticity of reproduction depends on rate of warming across generations. Evol Appl. 9, 1072-1081. doi: 10.1111/eva.12386.

Dorts, J., Grenouillet, G., Douxfils, J., Mandiki, S.N., Milla, S., Silvestre, F., Kestemont, P. 2012. Evidence that elevated water temperature affects the reproductive physiology of the European bullhead Cottus gobio. Fish Physiol Biochem. 38(2):389-99.

Dudley, R.G., Eipper, A.W., 1975. Survival of Largemouth Bass Embryos at Low Dissolved Oxygen Concentrations. Transactions of the American Fisheries Society. 104, 122-128. doi: 10.1577/15488659(1975)104<122:SOLBEA>2.0.CO;2.

Dufour, S., Sebert, M.E., Weltzien, F.A., Rousseau, K., Pasqualini, C. 2010. Neuroendocrine control by dopamine of teleost reproduction. J Fish Biol. 76(1):129-160.

Dulka, J.G., 1993. Sex pheromone systems in goldfish: Comparisons to vomeronasal systems in tetrapods. Brain Behavior and Evolution. 42, 265-280. 
Durant, J.M., Hjermann, D.O., Ottersen, G., Stenseth, N.C., 2007. Climate and the match or mismatch between predator requirements and resource availability. Climate Research. 33, 271-283.

Eales, J.G., Brown, S.B., 1993. Measurement and regulation of thyroidal status in teleost fish. Reviews in Fish Biology and Fisheries. 3, 299-347. doi: 10.1007/bf00043383.

Eales, J.G., Chang, J.P., Van Der Kraak, G., Omeljaniuk, R.J., Uin, L., 1982. Effects of temperature on plasma thyroxine and lodide kinetics in rainbow trout, Salmo gairdneri. General and Comparative Endocrinology. 47, 295-307. doi: 10.1016/0016-6480(82)90237-4.

Effer, B., Figueroa, E., Augsburger, A., Valdebenito, I., 2013. Sperm biology of Merluccius australis: Sperm structure, semen characteristics and effects of $\mathrm{pH}$, temperature and osmolality on sperm motility. Aquaculture. 408-409, 147-151. doi: 10.1016/j.aquaculture.2013.05.040.

Ekström, P., Meissl, H. 1997. The pineal organ of teleost fishes. Rev Fish Biol Fisheries. 7: 199-284.

Elisio, M., Chalde, T., Miranda, L.A., 2012. Effects of short periods of warm water fluctuations on reproductive endocrine axis of the pejerrey (Odontesthes bonariensis) spawning. Comp Biochem Physiol A Mol Integr Physiol. 163, 47-55. doi: 10.1016/j.cbpa.2012.05.178.

Falcón, J., Besseau, L., Boeuf, G. 2007. Molecular and cellular regulation of pineal organ responses, pp. 203-406. In Sensory Systems Neuroscience. Fish Physiology. Edited by T. Hara and B. Zielinski. Academic Press Elsevier, Amsterdam.

Falcón, J., Migaud, H., Muñoz-Cueto, J.A., Carrillo, M. 2010. Current knowledge on the melatonin system in teleost fish. Gen Comp Endocrinol. 165(3): 469-482.

Faria, A.M., Lopes, A.F., Silva, C.S.E., Novais, S.C., Lemos, M.F.L., Goncalves, E.J., 2018. Reproductive trade-offs in a temperate reef fish under high pCO2 levels. Mar Environ Res. 137, 8-15. doi: 10.1016/j.marenvres.2018.02.027.

Fauvel, C., Omnès, M.-H., Suquet, M., Normant, Y., 1993. Reliable assessment of overripening in turbot (Scophthalmus maximus) by a simple pH measurement. Aquaculture. 117, 107-113. doi: 10.1016/0044-8486(93)90127-K.

Fenkes, M., Fitzpatrick, J.L., Ozolina, K., Shiels, H.A., Nudds, R.L., 2017. Sperm in hot water: direct and indirect thermal challenges interact to impact on brown trout sperm quality. J Exp Biol. 220, 25132520. doi: 10.1242/jeb.156018.

Field, C.B., Barros, V.R., Mach, K.J., Mastrandrea, M.D., Van Aalst, R., Adger, W.N., Arent, D.J., Barnett, J., Betts, R.A., Bilir, T.E., 2014. Technical summary.

Fontaine, M., 1976. Physiological Mechanisms in the Migration of Marine and Amphihaline Fish. in: Russell, F.S., Yonge, M., (Eds.), Advances in Marine Biology, Academic Press, pp. 241-355.

Forlano, P.M., Bass, A.H., 2011. Neural and hormonal mechanisms of reproductive-related arousal in fishes. Hormones and behavior. 59, 616-629. doi: 10.1016/j.yhbeh.2010.10.006.

Forsgren, E., Dupont, S., Jutfelt, F., Amundsen, T., 2013. Elevated CO2 affects embryonic development and larval phototaxis in a temperate marine fish. Ecol Evol. 3, 3637-3646. doi: 10.1002/ece3.709.

Füssel, H.-M., Hallegatte, S., Reder, M., 2012. International Adaptation Funding. in: Edenhofer, O., Wallacher, J., Lotze-Campen, H., Reder, M., Knopf, B., Müller, J., (Eds.), Climate Change, Justice and Sustainability: Linking Climate and Development Policy, Springer Netherlands, Dordrecht, pp. 311-330.

Gallego, V., Asturiano, J.F., 2019. Fish sperm motility assessment as a tool for aquaculture research: a historical approach. Reviews in Aquaculture.doi: 10.1111/raq.12253. 
García-Allegue, R., Madrid, J.A., Sánchez-Vázquez, F.J. 2001. Melatonin rhythms in European sea bass plasma and eye: influence of seasonal photoperiod and water temperature. J Pineal Res. 31: 6875.

Gattuso, J.P., Magnan, A., Bille, R., Cheung, W.W., Howes, E.L., Joos, F., et al., 2015. OCEANOGRAPHY. Contrasting futures for ocean and society from different anthropogenic $\mathrm{CO}(2)$ emissions scenarios. Science. 349, aac4722. doi: 10.1126/science.aac4722.

Gau, P., Poon, J., Ufret-Vincenty, C., Snelson, C.D., Gordon, S.E., Raible, D.W., Dhaka, A., 2013. The Zebrafish Ortholog of TRPV1 is Required for Heat-Induced Locomotion. The Journal of Neuroscience. 33, 5249-5260. doi: 10.1523/jneurosci.5403-12.2013.

Gillet, C., 1991. Egg production in an Arctic charr (Salvelinus alpinus L.) brood stock: effects of temperature on the timing of spawning and the quality of eggs. Aquat. Living Resour. 4, 109-116.

Gillet, C., Breton, B. 2009. LH secretion and ovulation following exposure of Arctic charr to different temperature and photoperiod regimes: responsiveness of females to a gonadotropin-releasing hormone analogue and a dopamine antagonist. Gen. Comp. Endocrinol., 162 : 210-221.

Gillet, C., Breton, B., Mikolajczyk, T., 1996. Effects of GnRHa and pimozide treatments on the timing of ovulation and on egg quality in Arctic charr (Salvelinus alpinus) at 5 and $10{ }^{\circ} \mathrm{C}$. Aquat. Living Resour. 9, 257-263.

Gillet, C., Breton, B., Mikolajczyk, T., Bodinier, P., Fostier, A., 2011. Disruption of the secretion and action of 17,20beta-dihydroxy-4-pregnen-3-one in response to a rise in temperature in the Arctic charr, Salvelinus alpinus. Consequences on oocyte maturation and ovulation. Gen Comp Endocrinol. 172, 392-399. doi: 10.1016/j.ygcen.2011.04.002.

Golan, M., Zelinger, E., Zohar, Y., Levavi-Sivan, B., 2015. Architecture of GnRH-GonadotropeVasculature Reveals a Dual Mode of Gonadotropin Regulation in Fish. Endocrinology. 156, 41634173. doi: 10.1210/en.2015-1150.

Gracheva, E.O., Bagriantsev, S.N., 2015. Evolutionary adaptation to thermosensation. Curr Opin Neurobiol. 34, 67-73. doi: 10.1016/j.conb.2015.01.021.

Green, L., Jutfelt, F., 2014. Elevated carbon dioxide alters the plasma composition and behaviour of a shark. Biology Letters. 10, 20140538 doi: 10.1098/rsbl.2014.0538.

Guiguen, Y., Baroiller, J.F., Ricordel, M.J., Iseki, K., Mcmeel, O.M., Martin, S.A., Fostier, A., 1999. Involvement of estrogens in the process of sex differentiation in two fish species: the rainbow trout (Oncorhynchus mykiss) and a tilapia (Oreochromis niloticus). Mol Reprod Dev. 54, 154-162. doi: 10.1002/(sici)1098-2795(199910)54:2<154::Aid-mrd7>3.0.Co;2-5.

Guiguen, Y., Fostier, A., Piferrer, F., Chang, C.F., 2010. Ovarian aromatase and estrogens: a pivotal role for gonadal sex differentiation and sex change in fish. Gen Comp Endocrinol. 165, 352-366. doi: 10.1016/j.ygcen.2009.03.002.

Haddy, J. A., Pankhurst, N. W., 2000. The effects of salinity on reproductive development, plasma steroid levels, fertilisation and egg survival in black bream Acanthopagrus butcheri. Aquaculture. 188: 115-131.

Hagiwara, A., Ogiwara, K., Katsu, Y., Takahashi, T., 2014. Luteinizing hormone-induced expression of Ptger4b, a prostaglandin E2 receptor indispensable for ovulation of the medaka Oryzias latipes, is regulated by a genomic mechanism involving nuclear progestin receptor. Biol Reprod. 90, 126. doi: 10.1095/biolreprod.113.115485.

Hale, R., 2008. Evidence that context-dependent mate choice for parental care mirrors benefits to offspring. Animal Behaviour 75. 1283-1290. doi: 10.1016/j.anbehav.2007.09.034. 
Hamor, T., Garside, E.T., 1976. Developmental rates of embryos of Atlantic salmon, Salmo salar L., in response to various levels of temperature, dissolved oxygen, and water exchange. Can J Zool. 54, 1912-1917.

Hattori, R. S., Fernandino, J. I., Kishii, A., Kimura, H., Kinno, T., Oura, M., Somoza, G.M., Yokota, M., Strüssmann, C.A., Watanabe, S., 2009. Cortisol-induced masculinization: does thermal stress affect gonadal fate in pejerrey, a teleost fish with temperature-dependent sex determination? PLoS One 4, e6548. doi: 10.1371/journal.pone.0006548.

Hayashi, Y., Kobira, H., Yamaguchi, T., Shiraishi, E., Yazawa, T., Hirai, T., Kamei, Y., Kitano, T., 2010. High temperature causes masculinization of genetically female medaka by elevation of cortisol. Mol. Reprod. Dev. 77, 679-686. doi: 10.1002/mrd.21203.

Helfman, G., Collette, B., Facey, D., Bowen, B., 2009. The Diversity of Fishes: Biology, Evolution, and Ecology. Wiley-Blackwell edition.

Hoffmann, A.A., Sgro, C.M., 2011. Climate change and evolutionary adaptation. Nature. 470, 479485. doi: $10.1038 /$ nature09670.

Huertas, M., Almeida, O.G., Canario, A.V., Hubbard, P.C., 2014. Tilapia male urinary pheromone stimulates female reproductive axis. General and Comparative Endrocrinology. 196, 106-111. doi: 10.1016/j.ygcen.2013.11.024.

Hutchings, J., Myers, R.A., 1994. Timing of cod reproduction - Interannual variability and the influence of temperature. Marine Ecology-progress Series 108: 21-31. doi: 10.3354/meps108021.

ligo, M., Aida, K. 1995. Effects of season, temperature and photoperiod on plasma melatonin rhythms in goldfish, Carassius auratus. J Pineal Res. 18: 62-68.

Ishimatsu, A., Hayashi, M., Kikkawa, T., 2008. Fishes in high-CO2, acidified oceans. Marine Ecology Progress Series. 373, 295-302. doi: 10.3354/meps07823.

Ito, L.S., Cornejo, A.M., Yamashita, M., Strüssmann, C.A. 2008. Thermal threshold and histological process of heat-induced sterility in adult pejerrey (Odontesthes bonariensis): a comparative analysis of laboratory and wild specimens. Physiol Biochem Zool. 81(6):775-84. doi: 10.1086/591035.

Jobling, M., Johnsen, H.K., Pettersen, G.W., Henderson, R.J., 1995. Effect of temperature on reproductive development in Arctic charr, Salvelinus alpinus (L.). Journal of Thermal Biology. 20, 157-165. doi: 10.1016/0306-4565(94)00044-J.

Jonsson, B., Jonsson, N. 2009. A review of the likely effects of climate change on anadromous Atlantic salmon Salmo salar and brown trout Salmo trutta, with particular reference to water temperature and flow. J Fish Biol. 75(10):2381-447. doi: 10.1111/j.1095-8649.2009.02380.x.

Jutfelt, F., De Souza, K.B., Vuylsteke, A., Sturve, J., 2013. Behavioural disturbances in a temperate fish exposed to sustained high-CO2 levels. PLoS ONE. 8, e65825. doi: 10.1371/journal.pone.0065825.

Kah, O., Lethimonier, C., Somoza, G., Guilgur, L.G., Vaillant, C., Lareyre, J.J. 2007. GnRH and GnRH receptors in metazoa: A historical, comparative, and evolutive perspective. Gen Comp Endocrinol. 153: 346-364.

Kah, O., Anglade, I., Leprétre, E., Dubourg, P., de Monbrison, D. 1993. The reproductive brain in fish. Fish Physiol Biochem. 11:85-98.

Kah, O., Dulka, J.G., Dubourg, P., Thibault, J., Peter, R.E. 1987.Neuroanatomical substrate for the inhibition of gonadotropin secretion in goldfish: existence of a dopaminergic preopticohypophyseal pathway. Neuroendocrinology. 45: 451-458. 
Kah, O., Danger, J.M., Dubourg, P., Pelletier, G., Vaudry, H., Calas, A. 1989. Characterization, cerebral distribution and gonadotropin-release activity of neuropeptide $Y$ (NPY) in the goldfish. Fish Physiol Biochem. 7: 69-76.

Kah, O., Trudeau, V.L. , Sloley, B.D., Duborg, P., Chang, J.P., Yu, K.L., Peter, R.E. 1992. Involvement of GABA in the neuroendocrine regulation of gonadotrophin release in the goldfish.Neuroendocrinology. 55: 396-404.

Keeling, R.F., Garcia, H.E., 2002. The change in oceanic 0-2 inventory associated with recent global warming. Proceedings of the National Academy of Sciences of the United States of America. 99, 7848-7853. doi: 10.1073/pnas.122154899.

Keller-Costa, T., Canario, A.V., Hubbard, P.C., 2015. Chemical communication in cichlids: A minireview. Gen Comp Endocrinol. 221, 64-74. doi: 10.1016/j.ygcen.2015.01.001.

Khan, I.A., Thomas, P., 1999. GABA exerts stimulatory and inhibitory influences on gonadotropin II secretion in the Atlantic croaker (Micropogonias undulatus). Neuroendocrinology. 69, 261-268.

Kikkawa, T., Ishimatsu, A., Kita, J., 2003. Acute $\mathrm{CO} 2$ tolerance during the early developmental stages of four marine teleosts. Environ Toxicol. 18, 375-382. doi: 10.1002/tox.10139.

King, H., Pankhurst, N., Watts, M., 2007. Reproductive sensitivity to elevated water temperatures in female Atlantic salmon is heightened at certain stages of vitellogenesis. Journal of Fish Biology. 70. doi: 10.1111/j.1095-8649.2006.01295.x.

King, H.R., Pankhurst, N.W., Watts, M., Pankhurst, P.M., 2003. Effect of elevated summer temperatures on gonadal steroid production, vitellogenesis and egg quality in female Atlantic salmon. Journal of Fish Biology. 63, 153-167. doi: 10.1046/j.1095-8649.2003.00137.x.

Kjørsvik, E., Mangor-Jensen, A., Holmefjord, I., 1990. Egg quality in marine fishes. Adv. Mar. Biol. 26: 71-113.

Koide, T., Yabuki, Y., Yoshihara, Y., 2018. Terminal Nerve GnRH3 Neurons Mediate Slow Avoidance of Carbon Dioxide in Larval Zebrafish. Cell Rep. 22, 1115-1123. doi: 10.1016/j.celrep.2018.01.019.

Labbé, C., Maisse, G., 1996. Influence of rainbow trout thermal acclimation on sperm cryopreservation: relation to change in the lipid composition of the plasma membrane. Aquaculture. 145, 281-294. doi: 10.1016/S0044-8486(96)01354-3.

Labbe, C., Maisse, G., 2001. Characteristics and freezing tolerance of brown trout spermatozoa according to rearing water salinity. Aquaculture. 201, 287-299. doi: 10.1016/S00448486(01)00607-X.

Lahiri, K., Vallone, D., Gondi, S.B., Santoriello, C., Dickmeis, T., et al. 2005. Temperature regulates transcription in the zebrafish circadian clock. PLoS Biol. 3: e351.

Lahnsteiner, F., Kletzl, M. 2012. The effect of water temperature on gamete maturation and gamete quality in the European grayling (Thymalus thymallus) based on experimental data and on data from wild populations. Fish Physiol Biochem. 38(2):455-67. doi: 10.1007/s10695-011-9526-8.

Lahnsteiner, F., Leitner, S. 2013. Effect of temperature on gametogenesis and gamete quality in brown trout, Salmo trutta. J Exp Zool A Ecol Genet Physiol. 319(3):138-48. doi: 10.1002/jez.1779. Epub 2013 Jan 11.

Lahnsteiner, F., 2000. Morphological, physiological and biochemical parameters characterizing the over-ripening of rainbow trout eggs. Fish Physiology and Biochemistry. 23, 107-118. doi: 10.1023/a:1007839023540.

Lai, K.P., Li, J.W., Tse, A.C., Chan, T.F., Wu, R.S., 2016a. Hypoxia alters steroidogenesis in female marine medaka through miRNAs regulation. Aquat Toxicol. 172, 1-8. doi: 10.1016/j.aquatox.2015.12.012. 
Lai, K.P., Li, J.W., Tse, A.C., Cheung, A., Wang, S., Chan, T.F., Kong, R.Y., Wu, R.S., 2016b. Transcriptomic responses of marine medaka's ovary to hypoxia. Aquat Toxicol. 177, 476-483. doi: 10.1016/j.aquatox.2016.06.023.

Lai, K.P., Li, J.W., Wang, S.Y., Wan, M.T., Chan, T.F., Lui, W.Y., Au, D.W., Wu, R.S., Kong, R.Y., 2018. Transcriptomic analysis reveals transgenerational effect of hypoxia on the neural control of testicular functions. Aquat Toxicol. 195, 41-48. doi: 10.1016/j.aquatox.2017.12.005.

Lai, K.P., Wang, S.Y., Li, J.W., Tong, Y., Chan, T.F., Jin, N., Tse, A., Zhang, J.W., Wan, M.T., Tam, N., Au, D.W.T., Lee, B.Y., Lee, J.S., Wong, A.S.T., Kong, R.Y.C., Wu, R.S.S., 2019. Hypoxia Causes Transgenerational Impairment of Ovarian Development and Hatching Success in Fish. Environ Sci Technol. 53, 3917-3928. doi: 10.1021/acs.est.8b07250.

Landry, C.A., Steele, S.L., Manning, S., Cheek, A.O., 2007. Long term hypoxia suppresses reproductive capacity in the estuarine fish, Fundulus grandis. Comparative Biochemistry and Physiology aMolecular \& Integrative Physiology. 148, 317-323. doi: 10.1016/j.cbpa.2007.04.023.

Lastein, S., Hamdani, E.H., Døving, K.B., 2014. Olfactory Discrimination of Pheromones. Fish Pheromones and Related Cues, John Wiley \& Sons, Inc, pp. 159-195.

Lavett Smith, C., 1992. Reproductive Seasonality in Teleosts: Environmental Influences. Angus D. Munro Alexander P. Scott T. J. Lam. CRC Press Published.

Lee, S., Ji, K., Choi, K., 2014. Effects of water temperature on perchlorate toxicity to the thyroid and reproductive system of Oryzias latipes. Ecotoxicol Environ Saf. 108, 311-317. doi: 10.1016/j.ecoenv.2014.07.016.

Lehtonen, T.K., Wong, B.B., Kvarnemo, C., 2016. Effects of salinity on nest-building behaviour in a marine fish. BMC Ecol. 16, 7. doi: 10.1186/s12898-016-0067-y.

Lethimonier, C., Madigou, T., Muñoz-Cueto, J.A., Lareyre, J.J., Kah, O. 2004. Evolutionary aspects of GnRHs, GnRH neuronal systems and GnRH receptors in teleost fish. Gen Comp Endocrinol. 135: 116.

Levy, G., David, D., Degani, G. 2011. Effect of environmental temperature on growth-and reproduction-related hormones gene expression in the female blue gourami (Trichogaster trichopterus). Comp. Biochem. Physiol. A, 160: 381-389.

Lim, B.-S., Kagawa, H., Gen, K., Okuzawa, K., 2003. Effects of water temperature on the gonadal development and expression of steroidogenic enzymes in the gonad of juvenile red seabream, Pagrus major. Fish Physiology and Biochemistry. 28, 161-162. doi: 10.1023/b:Fish.0000030511.73742.35.

López-Olmeda, J.F., Sánchez-Vázquez, F.J. 2011. Thermal biology of zebrafish. (Danio reiro). J Therm Biol 36: 91-104.

López-Olmeda, J.F., Sánchez-Vázquez, F.J 2009. Zebrafish temperature selection and synchronization of locomotor activity circadian rhythm to ahemeral cycles of light and temperature. Chronobiol Int. 26(2):200-18.

Lu, X., Yu, R. M. K., Murphy, M. B., Lau, K. and Wu, R. S. S. 2014. Hypoxia disrupts gene modulation along the brain-pituitary-gonad (BPG)-liver axis. Ecotoxicol. Environ. Saf. 102: 70-78.

Magnotti, C., Figueroa, E., Farias, J.G., Merino, O., Valdebenito, I., Oliveira, R.P.S., Cerqueira, V., 2018. Sperm characteristics of wild and captive lebranche mullet Mugil liza (Valenciennes, 1836), subjected to sperm activation in different pH and salinity conditions. Anim Reprod Sci. 192, 164170. doi: 10.1016/j.anireprosci.2018.03.004.

Majhi, R.K., Kumar, A., Yadav, M., Swain, N., Kumari, S., Saha, A., Pradhan, A., Goswami, L., Saha, S., Samanta, L., Maity, A., Nayak, T.K., Chattopadhyay, S., Rajakuberan, C., Kumar, A., Goswami, C., 
2013. Thermosensitive ion channel TRPV1 is endogenously expressed in the sperm of a fresh water teleost fish (Labeo rohita) and regulates sperm motility. Channels (Austin). 7, 483-492. doi: 10.4161/chan.25793.

Mananos, E.L., Anglade, I., Chyb, J., Saligaut, C., Breton, B., Kah, O., 1999. Involvement of gammaaminobutyric acid in the control of GTH-1 and GTH-2 secretion in male and female rainbow trout. Neuroendocrinology. 69, 269-280.

Manning, N.J., Kime, D.E., 1985. The effect of temperature on testicular steroid production in the rainbow trout, Salmo gairdneri, in vivo and in vitro. General and Comparative Endocrinology. 57, 377-382. doi: 10.1016/0016-6480(85)90217-5.

Mansour, N., Lahnsteiner, F., Patzner, R.A., 2007. Distribution of lipid droplets is an indicator for egg quality in brown trout, Salmo trutta fario. Aquaculture. 273, 744-747. doi: 10.1016/j.aquaculture.2007.09.027.

Marks, C., Kaut, K.P., Moore, F.B., Bagatto, B., 2012. Ontogenetic oxygen changes alter zebra fish size, behavior, and blood glucose. Physiol Biochem Zool. 85, 635-644. doi: 10.1086/666508.

Marshall, J. D., Uller, T., 2007. When is maternal effect adaptive? Oikos 116, 1957-1963. doi:10.1111/j.2007.0030-1299.16203.x

Matear, R.J., Hirst, A.C., 2003. Long-term changes in dissolved oxygen concentrations in the ocean caused by protracted global warming. Global Biogeochemical Cycles. 17. doi: 10.1029/2002gb001997.

Matear, R.J., Hirst, A.C., Mcneil, B.I., 2000. Changes in dissolved oxygen in the Southern Ocean with climate change. Geochem Geophys Geosyst. 1.

Meier, K., Hansen, M.M., Normandeau, E., Mensberg, K.L., Frydenberg, J., Larsen, P.F., Bekkevold, D., Bernatchez, L., 2014. Local adaptation at the transcriptome level in brown trout: evidence from early life history temperature genomic reaction norms. PLoS One. 9, e85171. doi: 10.1371/journal.pone.0085171.

Meinshausen, M., Raper, S.C.B., Wigley, T.M.L., 2011. Emulating coupled atmosphere-ocean and carbon cycle models with a simpler model, MAGICC6 - Part 1: Model description and calibration. Atmospheric Chemistry and Physics. 11, 1417-1456. doi: 10.5194/acp-11-1417-2011.

Migaud, H., Fontaine, P., Sulistyo, I., Kestemont, P., Gardeur, J.N., 2002. Induction of out-of-season spawning in Eurasian perch Perca fluviatilis: effects of rates of cooling and cooling durations on female gametogenesis and spawning. Aquaculture 205, 253-267.

Milazzo, M., Cattano, C., Alonzo Suzanne, H., Foggo, A., Gristina, M., Rodolfo-Metalpa, R., Sinopoli, M., Spatafora, D., Stiver Kelly, A., Hall-Spencer Jason, M., 2016b. Ocean acidification affects fish spawning but not paternity at $\mathrm{CO} 2$ seeps. Proceedings of the Royal Society B: Biological Sciences. 283, 20161021. doi: 10.1098/rspb.2016.1021.

Milazzo, M., Cattano, C., Alonzo, S.H., Foggo, A., Gristina, M., Rodolfo-Metalpa, R., Sinopoli, M., Spatafora, D., Stiver, K.A., Hall-Spencer, J.M., 2016a. Ocean acidification affects fish spawning but not paternity at CO2 seeps. Proc Biol Sci. 283. doi: 10.1098/rspb.2016.1021.

Milla, S., Wang, N., Mandiki, S. N. M. and Kestemont, P. 2009. Corticosteroids: friends or foes of teleost reproduction? Comp. Biochem. Physiol. 153A, 242-251.

Miller, G.M., Kroon, F.J., Metcalfe, S., Mundayi, P.L., 2015. Temperature is the evil twin: effects of increased temperature and ocean acidification on reproduction in a reef fish. Ecol Appl. 25, 603620. 
Miller, G.M., Watson, S.-A., Donelson, J.M., Mccormick, M.I., Munday, P.L., 2012. Parental environment mediates impacts of increased carbon dioxide on a coral reef fish. Nature Climate Change. 2, 858-861. doi: 10.1038/nclimate1599.

Miller, G.M., Watson, S.A., Mccormick, M.I., Munday, P.L., 2013. Increased CO2 stimulates reproduction in a coral reef fish. Glob Chang Biol. 19, 3037-3045. doi: 10.1111/gcb.12259.

Millero, F.J., Graham, T.B., Huang, F., Bustos-Serrano, H., Pierrot, D., 2006. Dissociation constants of carbonic acid in seawater as a function of salinity and temperature. Marine Chemistry. 100, 80-94. doi: 10.1016/j.marchem.2005.12.001.

Miranda, L.A., Chalde, T., Elisio, M., Strüssmann, C.A., 2013. Effects of global warming on fish reproductive endocrine axis, with special emphasis in pejerrey Odontesthes bonariensis. General and Comparative Endocrinology. 192, 45-54. doi: 10.1016/j.ygcen.2013.02.034.

Moniruzzaman, M., Mukherjee, J., Jacquin, L., Mukherjee, D., Mitra, P., Ray, S., Chakraborty, S.B., 2018. Physiological and behavioural responses to acid and osmotic stress and effects of Mucuna extract in Guppies. Ecotoxicol Environ Saf. 163, 37-46. doi: 10.1016/j.ecoenv.2018.07.053.

Morisawa, M., Suzuki, K., 1980. Osmolality and potassium ion: their roles in initiation of sperm motility in teleosts. Science. 210, 1145-1147. doi: 10.1126/science.7444445.

Morisawa, M., Suzuki, K., Morisawa, S., 1983. Effects of potassium and osmolality on spermatozoan motility of salmonid fishes. J Exp Biol. 107, 105-113.

Muller, K., Muller, P., Pincemy, G., Kurz, A., Labbe, C., 2008. Characterization of sperm plasma membrane properties after cholesterol modification: consequences for cryopreservation of rainbow trout spermatozoa. Biol Reprod. 78, 390-399. doi: 10.1095/biolreprod.107.064253.

Munday, P.L., Mccormick, M.I., Nilsson, G.E., 2012. Impact of global warming and rising CO2 levels on coral reef fishes: what hope for the future? J Exp Biol. 215, 3865-3873. doi: 10.1242/jeb.074765.

Munday, P.L., Warner, R.R., Monro, K., Pandolfi, J.M., Marshall, D.J., 2013. Predicting evolutionary responses to climate change in the sea. Ecology Letters. 16, 1488-1500. doi: 10.1111/ele.12185.

Munday, P.L., Watson, S.A., Chung, W.S., Marshall, N.J., Nilsson, G.E., 2014. Response to 'the importance of accurate $\mathrm{CO} 2$ dosing and measurement in ocean acidification studies'. J Exp Biol. 217, 1828-1829. doi: 10.1242/jeb.105890.

Munday, P.L., Watson, S.-A., Parsons, D.M., King, A., Barr, N.G., Mcleod, I.M., Allan, B.J.M., Pether, S.M.J., 2016a. Effects of elevated CO2 on early life history development of the yellowtail kingfish, Seriola lalandi, a large pelagic fish. ICES Journal of Marine Science. 73, 641-649. doi: 10.1093/icesjms/fsv210.

Munday, P.L., Welch, M.J., Allan, B.J.M., Watson, S.-A., Mcmahon, S.J., Mccormick, M.I., 2016b. Effects of elevated $\mathrm{CO} 2$ on predator avoidance behaviour by reef fishes is not altered by experimental test water. Peerj. 4, e2501. doi: 10.7717/peerj.2501.

Muñoz-Cueto, J.A., Paullada-Salmerón, J.A., Aliaga-Guerrero, M., Cowan, M.E., Parhar, I.S., Ubuka, T. 2017. A journey through the gonadotropin-inhibitory hormone system of fish. Front Endocrinol (Lausanne). 8:285.

Navarro-Martín, L., Viñas, J., Ribas, L., Díaz, N., Gutiérrez, A., Di Croce, L., Piferrer, F., 2011. DNA methylation of the gonadal aromatase (сур19a) promoter is involved in temperature-dependent sex ratio shifts in the European sea bass. PLoS Genet. 12, e1002447.

Newman, D.M., Jones, P.L., Ingram, B.A., 2010. Advanced ovarian development of Murray cod Maccullochella peelii peelii via phase-shifted photoperiod and two temperature regimes. Aquaculture. 310, 206-212. doi: 10.1016/j.aquaculture.2010.08.024 
Nilsson, G. E., Dixson, D. L., Domenici, P., McCormick, M. I., Sørensen, C., Watson, S.-A., \& Munday, P. L. 2012. Near-future carbon dioxide levels alter fish behaviour by interfering with neurotransmitter function. Nature Climate Change 2(3): 201-204.

Ninness, M., D. Stevens, Wright P. 2011. Energy expenditure during hatching in rainbow trout (Oncorhynchus mykiss) embryos. Canadian Journal of Fisheries and Aquatic Sciences 63: 14051413.

Nissling, A., Johansson, U., Jacobsson, M., 2006. Effects of salinity and temperature conditions on the reproductive success of turbot (Scophthalmus maximus) in the Baltic Sea. Fisheries Research. 80, 230-238. doi: 10.1016/j.fishres.2006.04.005.

Nissling, A., Larsson, R., 2018. Population specific sperm production in European flounder Platichthys flesus: Adaptation to salinity at spawning. J Fish Biol. 93, 47-52. doi: 10.1111/jfb.13667.

Nissling, A., Nyberg, S., Petereit, C., 2017. Egg buoyancy of flounder, Platichthys flesus, in the Baltic Sea-adaptation to salinity and implications for egg survival. Fisheries Research. 191, 179-189. doi: 10.1016/j.fishres.2017.02.020.

Nissling, A., Westin, L., Hjerne, O., 2002. Reproductive success in relation to salinity for three flatfish species, dab ( Limanda limanda), plaice (Pleuronectes platessa), and flounder (Pleuronectes flesus ), in the brackish water Baltic Sea. ICES Journal of Marine Science. 59, 93-108. doi: 10.1006/jmsc.2001.1134.

Okuzawa, K., Kumakura, N., Gen, K., Yamaguchi, S., Lim, B., Kagawa, H. 2003. Effect of high water temperature on brain-pituitary-gonad axis of the red seabream during its spawning season. Fish Physiol. Biochem. 28: 439-440.

Pankhurst, N.W., King, H.R., 2010. Temperature and salmonid reproduction: implications for aquaculture. Journal of Fish Biology. 76, 69-85. doi: 10.1111/j.1095-8649.2009.02484.x.

Pankhurst, N.W., Porter, M.J.R., 2003. Cold and dark or warm and light: variations on the theme of environmental control of reproduction. Fish Physiology and Biochemistry. 28, 385-389. doi: 10.1023/b:fish.0000030602.51939.50.

Pankhurst, N.W., Purser, G.J., Van Der Kraak, G., Thomas, P.M., Forteath, G.N.R., 1996. Effect of holding temperature on ovulation, egg fertility, plasma levels of reproductive hormones and in vitro ovarian steroidogenesis in the rainbow trout Oncorhynchus mykiss. Aquaculture. 146, 277290. doi: 10.1016/S0044-8486(96)01374-9.

Pankhurst, N.W., Thomas, P.M., 1998. Maintenance at elevated temperature delays the steroidogenic and ovulatory responsiveness of rainbow trout Oncorhynchus mykiss to luteinizing hormone releasing hormone analogue. Aquaculture. 166, 163-177. doi: 10.1016/S00448486(98)00284-1.

Pankhurst, N.W., 2016. Reproduction and Development. In: Schreck, C.B., Tort, L., Farrell, A.P., Brauner, C.J. (Eds.), Biology of Stress in Fish. Fish Physiology Vol 35, Academic Press, pp 295-331.

Paullada-Salmerón, J.A;, Loentgen, G.H., Cowan, M.E., Aliaga-Guerrero, M., Rendón-Unceta, M.C., Muñoz-Cueto, J.A. 2017. Developmental changes and day-night expression of the gonadotropininhibitory hormone system in the European sea bass: effects of rearing temperature. Comp Biochem Physiol A 206:54-62

Paullada-Salmerón, J.A., Cowan, M., Aliaga-Guerrero, M., López-Olmeda, J.F., Mañanós, E.L., Zanuy, S., Muñoz-Cueto, J.A., 2016. Testicular steroidogenesis and locomotor activity are regulated by gonadotropin-inhibitory hormone in male European sea bass. PLoS One. 11(10): e0165494.

Penman, D.J., Piferrer, F., 2008. Fish Gonadogenesis. Part I: Genetic and Environmental Mechanisms of Sex Determination. Reviews in Fisheries Science. 16, 16-34. doi: 10.1080/10641260802324610. 
Peter, R.E., 1977. The Preoptic Nucleus in Fishes: A Comparative Discussion of Function-Activity Relationships. American Zoologist. 17, 775-785. doi: 10.1093/icb/17.4.775.

Piferrer, F., 2013. Epigenetics of sex determination and gonadogenesis. Dev Dyn. 242, 360-370. doi: 10.1002/dvdy.23924.

Piferrer, F., Blazquez, M., Navarro, L., Gonzalez, A., 2005. Genetic, endocrine, and environmental components of sex determination and differentiation in the European sea bass (Dicentrarchus labrax L.). Gen Comp Endocrinol. 142, 102-110. doi: 10.1016/j.ygcen.2005.02.011.

Piferrer, F., Ribas, L., Diaz, N., 2012. Genomic approaches to study genetic and environmental influences on fish sex determination and differentiation. Mar Biotechnol (NY). 14, 591-604. doi: 10.1007/s10126-012-9445-4.

Piomboni, P., Governini, L., Gori, M., Puggioni, E., Costantino-Ceccarini, E., Luddi, A., 2014. New players in the infertility of a mouse model of lysosomal storage disease: the hypothalamuspituitary-gonadal axis. Frontiers in endocrinology. 4, 204-204. doi: 10.3389/fendo.2013.00204.

Plattner, G.K., Joos, F., Stocker, T.F., Marchal, O., 2016. Feedback mechanisms and sensitivities of ocean carbon uptake under global warming. Tellus B: Chemical and Physical Meteorology. 53, 564-592. doi: 10.3402/tellusb.v53i5.16637.

Polymeropoulos, E., Elliott, N., Frappell, P., 2015. The maternal effect of differences in egg size influence metabolic rate and hypoxia induced hatching in Atlantic salmon eggs: implications for respiratory gas exchange across the egg capsule. Canadian Journal of Fisheries and Aquatic Sciences. 73. doi: 10.1139/cjfas-2015-0358.

Porteus, C.S., Hubbard, P.C., Uren Webster, T.M., Van Aerle, R., Canário, A.V.M., Santos, E.M., Wilson, R.W., 2018. Near-future CO2 levels impair the olfactory system of a marine fish. Nature Climate Change. 8, 737-743. doi: 10.1038/s41558-018-0224-8.

Pörtner, H.O., Farrell, A.P., 2008. Physiology and Climate Change. Science. 322, 690. doi: 10.1126/science.1163156.

Pörtner, H. O., Karl, D. M., Boyd, P. W., Cheung, W. W., Lluch-Cota, L. S. E., Nojiri, Y., Schmidt, D. N., Zavialov, P. O. 2014. Ocean systems. Climate Change 2014: Impacts, Adaptation, and Vulnerability. Part A: Global and Sectoral Aspects. Contribution of Working Group II to the Fifth Assessment Report of the Intergovernmental Panel on Climate Change. C. B. Field, V. R. Barros, D. J. Dokken et al. ambridge, United Kingdom and New York, NY, USA: 411-484.

Portner, H.O., Peck, M.A., 2010. Climate change effects on fishes and fisheries: towards a cause-andeffect understanding. J Fish Biol. 77, 1745-1779. doi: 10.1111/j.1095-8649.2010.02783.x.

Randall, C.F., Bromage, N.R., Thorpe, J.E., Miles, M.S, Muir, J.S. 1995. Melatonin rhythms in Atlantic salmon (Salmo salar) maintained under natural and out-of-phase photoperiods. Gen Comp Endocrinol. 98:73-86.

Räsänen, K., Kruuk, L.E.B., 2007. Maternal effects and evolution at ecological time-scales. Functional Ecology. 21, 408-421. doi: 10.1111/j.1365-2435.2007.01246.x.

Reading, B., Andersen, L., Ryu, Y.-W., Mushirobira, Y., Todo, T., Hiramatsu, N., 2018. Oogenesis and Egg Quality in Finfish: Yolk Formation and Other Factors Influencing Female Fertility. Fishes. 3, 45. doi: 10.3390/fishes3040045.

Regan, M.D., Turko, A.J., Heras, J., Andersen, M.K., Lefevre, S., Wang, T., Bayley, M., Brauner, C.J., Huong Do, T.T., Phuong, N.T., Nilsson, G.E., 2016. Ambient CO2, fish behaviour and altered GABAergic neurotransmission: exploring the mechanism of $\mathrm{CO}$-altered behaviour by taking a hypercapnia dweller down to low CO2 levels. J Exp Biol. 219, 109-118. doi: 10.1242/jeb.131375.

Reiter, R.J. 1993. The melatonin rhythm: Both a clock and a calender. Experientia. 49:654-664. 
Rombough, P.J., 1988. 2 Respiratory Gas Exchange, Aerobic Metabolism, and Effects of Hypoxia During Early Life. in: Hoar, W.S., Randall, D.J., (Eds.), Fish Physiology, Academic Press, pp. 59-161.

Saha, S., Singh, K.M., Gupta, B.B.P. 2019. Melatonin synthesis and clock gene regulation in the pineal organ of teleost fish compared to mammals: Similarities and differences. Gen Comp Endocrinol. 279: 27-34.

Sakai, K., Nomura, M., Takashima, F., 1985. Characteristics of Naturally Spawned Eggs of Red Sea Bream. NIPPON SUISAN GAKKAISHI. 51, 1395-1399. doi: 10.2331/suisan.51.1395.

Salinas, S., Brown, S.C., Mangel, M., Munch, S.B., 2013. Non-genetic inheritance and changing environments. Non-Genetic Inheritance. 1. doi: 10.2478/ngi-2013-0005.

Sánchez-Vázquez, F.J., ligo, M., Madrid, J.A., Zamora, S., Tabata, M. 1997.Daily cycles in plasma and ocular melatonin in demand-fed sea bass, Dicentrarchus labrax L. J Comp Physiol. 167B: 409-415.

Sandra, G.-E., Norma, M.-M., 2009. Sexual determination and differentiation in teleost fish. Reviews in Fish Biology and Fisheries. 20, 101-121. doi: 10.1007/s11160-009-9123-4.

Saraiva, L.R., Korsching, S.I., 2007. A novel olfactory receptor gene family in teleost fish. Genome research. 17, 1448-1457. doi: 10.1101/gr.6553207.

Satou, M., Oka, Y., Kusunoki, M., Matsushima, T., Kato, M., Fujita, I., Ueda, K., 1984. Telencephalic and preoptic areas integrate sexual behavior in hime salmon (landlocked red salmon, Oncorhynchus nerka): results of electrical brain stimulation experiments. Physiol Behav. 33, 441447. doi: 10.1016/0031-9384(84)90167-7.

Schade, F.M., Clemmesen, C., Mathias Wegner, K., 2014. Within- and transgenerational effects of ocean acidification on life history of marine three-spined stickleback (Gasterosteus aculeatus). Marine Biology. 161, 1667-1676. doi: 10.1007/s00227-014-2450-6.

Schulte, P.M., Healy, T.M., Fangue, N.A., 2011. Thermal performance curves, phenotypic plasticity, and the time scales of temperature exposure. Integr Comp Biol. 51, 691-702. doi: 10.1093/icb/icr097.

Schulz, R.W., França, L.R., Lareyre, J.J., Le Gac, F., Chiarini-Garcia, H., Nóbrega, R.H., Miura, T. 2010. Spermatogenesis in fish. Gen. Comp. Endocrinol. 165: 390-411.

Schunter, C., Welch, Megan j., Ryu, T., Zhang, H., Berumen, Michael I., Nilsson, Göran e., Munday, Philip I., Ravasi, T., 2016. Molecular signatures of transgenerational response to ocean acidification in a species of reef fish. Nature Climate Change. 6, 1014. doi: 10.1038/nclimate3087. https://www.nature.com/articles/nclimate3087\#supplementary-information.

Scott, A., 1987. Reproductive Endocrinology of Fish. In: Fundamental of comparate vertebrate endocrinology. I. Chetser-Jones, P.M. Ingleton, J.G. Phillips. Plenum Publishing Corporation. pp. 223-256.

Senthilkumaran, B., Okuzawa, K., Gen, K., Kagawa, H., 2001. Effects of serotonin, GABA and neuropeptide $Y$ on seabream gonadotropin releasing hormone release in vitro from preopticanterior hypothalamus and pituitary of red seabream, Pagrus major. J Neuroendocrinol. 13, 395400.

Servili, A., Herrera-Perez, P., Del Carmen Rendon, M., Munoz-Cueto, J.A., 2013. Melatonin inhibits GnRH-1, GnRH-3 and GnRH receptor expression in the brain of the European Sea Bass, Dicentrarchus labrax. Int J Mol Sci. 14, 7603-7616. doi: 10.3390/ijms14047603.

Servili, A., Lethimonier, C., Lareyre, J.J., Lopez-Olmeda, J.F., Sanchez-Vazquez, F.J., Kah, O., MunozCueto, J.A., 2010. The Highly conserved gonadotropin-releasing hormone-2 form acts as a melatonin-releasing factor in the pineal of a teleost fish, the european sea bass Dicentrarchus labrax. Endocrinology. 151, 2265-2275. doi: 10.1210/en.2009-1207. 
Shama, L.N., Wegner, K.M., 2014. Grandparental effects in marine sticklebacks: transgenerational plasticity across multiple generations. J Evol Biol. 27, 2297-2307. doi: 10.1111/jeb.12490.

Shama, L.N.S., Strobel, A., Mark, F.C., Wegner, K.M., Marshall, D., 2014. Transgenerational plasticity in marine sticklebacks: maternal effects mediate impacts of a warming ocean. Functional Ecology. 28, 1482-1493. doi: 10.1111/1365-2435.12280.

Shang, E.H., Wu, R.S., 2004. Aquatic hypoxia is a teratogen and affects fish embryonic development. Environ Sci Technol. 38, 4763-4767.

Shang, E.H., Yu, R.M., Wu, R.S., 2006. Hypoxia affects sex differentiation and development, leading to a male-dominated population in zebrafish (Danio rerio). Environ Sci Technol. 40, 3118-3122.

Shields, R.J., Brown, N.P., Bromage, N.R., 1997. Blastomere morphology as a predictive measure of fish egg viability. Aquaculture. 155, 1-12. doi: 10.1016/S0044-8486(97)00105-1.

Silva, L., Antunes, A., 2017. Vomeronasal Receptors in Vertebrates and the Evolution of Pheromone Detection. Annual Review of Animal Biosciences. 5, 353-370. doi: 10.1146/annurev-animal022516-022801.

Sneddon, L.U., 2003. Trigeminal somatosensory innervation of the head of a teleost fish with particular reference to nociception. Brain Research. 972, 44-52. doi: 10.1016/S00068993(03)02483-1.

Sorensen, P.W., Hara, T.J., Stacey, N.E., 1991. Sex pheromones selectively stimulate the medial olfactory tracts of male goldfish. Brain Res. 558, 343-347.

Sorensen, P.W., Stacey, N.E., Chamberlain, K.J., 1989. Differing behavioral and endocrinological effects of two female sex pheromones on male goldfish. Hormones and Behavior. 23, 317-332.

Soria, F.N., Strüssmann, C.A., Miranda, L.A. 2008. High water temperatures impair the reproductive ability of the pejerrey fish Odontesthes bonariensis: effects on the hypophyseal-gonadal axis. Physiol Biochem Zool. 81(6):898-905. doi: 10.1086/588178.

Sower, S.A., 2015. Breaking Dogma on the Hypothalamic-Pituitary Anatomical Relations in Vertebrates. Endocrinology. 156, 3882-3884. doi: 10.1210/en.2015-1778.

St. Mary, C., Noureddine, G., Lindström, K., 2001. Environmental Effects on Male Reproductive Success and Parental Care in the Florida Flagfish Jordanella floridae. Ethology. 107. 1035 - 1052. doi: 10.1046/j.1439-0310.2001.00747.x.

Stacey, N., 2014. Hormonally Derived Pheromones in Teleost Fishes. in: Sorensen, P.W., Wisenden, B.D., (Eds.), Fish Pheromones and Related Cues, John Wiley \& Sons, Inc, pp. 33-88.

Stoddard, J.W., Parsons, J.E., Nagler, J.J., 2005. Early onset of embryonic mortality in sub-fertile families of rainbow trout (Oncorhynchus mykiss). Reprod Fertil Dev. 17, 785-790.

Stoss, J., 1983. 6 Fish Gamete Preservation and Spermatozoan Physiology. in: Hoar, W.S., Randall, D.J., Donaldson, E.M., (Eds.), Fish Physiology, Academic Press, pp. 305-350.

Strüssmann, C.A., Patiño, R., 1999. Sex determination, environmental. In: Knobil, E., Neill, J.D., (Eds.), Encyclopedia of Reproduction, Academic Press, New York, pp. 402-409.

Strüssmann, C.A., Saito, T., Usui, M., Yamada, H., Takashima, F., 1997. Thermal thresholds and critical period of thermolabile sex determination in two atherinid fishes, Odontesthes bonariensis and Patagonina hatcheri. Journal of Experimental Zoology. 278, 167-177. doi: 10.1002/(sici)1097010x(19970615)278:3<167::aid-jez6>3.0.co;2-m.

Sullivan, C.M., 1954. Temperature Reception and Responses in Fish. Journal of the Fisheries Research Board of Canada. 11, 153-170. doi: 10.1139/f54-013. 
Sundin, J., Vossen, L.E., Nilsson-Sköld, H., Jutfelt, F., 2017. No effect of elevated carbon dioxide on reproductive behaviors in the three-spined stickleback. Behavioral Ecology. 28, 1482-1491. doi: 10.1093/beheco/arx112.

Takemura, A., Rahman, M. S., Nakamura, S., Park, Y. J., Takano, K. 2004. Lunar cycles and reproductive activity in reef fishes with particular attention to rabbitfishes. Fish and Fisheries. 5, 317-328.

Tang, H., Liu, Y., Li, J., Yin, Y., Li, G., Chen, Y., Li, S., Zhang, Y., Lin, H., Liu, X., Cheng, C.H., 2016. Gene knockout of nuclear progesterone receptor provides insights into the regulation of ovulation by LH signaling in zebrafish. Sci Rep. 6, 28545. doi: 10.1038/srep28545.

Thomas, P., Rahman, M.S., 2009a. Biomarkers of hypoxia exposure and reproductive function in Atlantic croaker: A review with some preliminary findings from the northern Gulf of Mexico hypoxic zone. Journal of Experimental Marine Biology and Ecology. 381, S38-S50. doi: 10.1016/j.jembe.2009.07.008.

Thomas, P., Rahman, M.S., 2009b. Chronic hypoxia impairs gamete maturation in Atlantic croaker induced by progestins through nongenomic mechanisms resulting in reduced reproductive success. Environ Sci Technol. 43, 4175-4180.

Thomas, P., Rahman, M.S., 2010. Region-wide impairment of Atlantic croaker testicular development and sperm production in the northern Gulf of Mexico hypoxic dead zone. Mar Environ Res. 69 Suppl, S59-62. doi: 10.1016/j.marenvres.2009.10.017.

Thomas, P., Rahman, M.S., 2012. Extensive reproductive disruption, ovarian masculinization and aromatase suppression in Atlantic croaker in the northern Gulf of Mexico hypoxic zone. Proc Biol Sci. 279, 28-38. doi: 10.1098/rspb.2011.0529.

Thomas, P., Rahman, M.S., Khan, I.A., Kummer, J.A., 2007. Widespread endocrine disruption and reproductive impairment in an estuarine fish population exposed to seasonal hypoxia. Proc Biol Sci. 274, 2693-2701. doi: 10.1098/rspb.2007.0921.

Thomas, P., Rahman, M.S., Picha, M.E., Tan, W., 2015. Impaired gamete production and viability in Atlantic croaker collected throughout the $20,000 \mathrm{~km}(2)$ hypoxic region in the northern Gulf of Mexico. Mar Pollut Bull. 101, 182-192. doi: 10.1016/j.marpolbul.2015.11.001.

Trudeau, V.L., Martyniuk, C.J., Zhao, E., Hu, H., Volkoff, H., Decatur, W.A., Basak, A. 2012. Is secretoneurin a new hormone? Gen Comp Endocrinol. 175(1):10-18.

Trudeau, V.L., Sloley, B.D., Peter, R.E., 1993. GABA stimulation of gonadotropin-II release in goldfish: involvement of GABAA receptors, dopamine, and sex steroids. Am J Physiol. 265, R348-355. doi: 10.1152/ajpregu.1993.265.2.R348.

Tse, A.C., Li, J.W., Chan, T.F., Wu, R.S., Lai, K.P., 2015. Hypoxia induces miR-210, leading to antiapoptosis in ovarian follicular cells of marine medaka Oryzias melastigma. Aquat Toxicol. 165, 189-196. doi: 10.1016/j.aquatox.2015.06.002.

Tubbs, C., Thomas, P., 2009. Progestin Signaling through an Olfactory G Protein and Membrane Progestin Receptor- $\alpha$ in Atlantic Croaker Sperm: Potential Role in Induction of Sperm Hypermotility. Endocrinology. 150, 473-484. doi: 10.1210/en.2008-0512.

Tveiten, H., 2008. Temperature influence on reproductive development and gamete quality in Atlantic cod (Gadus morhua). Cybium: international journal of ichthyology. Conference: 8th International Symposium on Reproductive Physiology of FishVolume: 32.

Tveiten, H., Solevåg, S.E., Johnsen, H.K., 2001. Holding temperature during the breeding season influences final maturation and egg quality in common wolffish. Journal of Fish Biology. 58, 374385. doi: 10.1111/j.1095-8649.2001.tb02259.x. 
Vagner, M., Zambonino-Infante, J.L., Mazurais, D., 2019. Fish facing global change: are early stages the lifeline? Mar Environ Res. 147, 159-178. doi: 10.1016/j.marenvres.2019.04.005.

Van Der Kraak, G., Pankhurst, N., 1997. Temperature effects on the reproductive performance of fish, in : D.G. MacDonald, C.M. Wood (Eds.), Global warming: implications for freshwater and marine fish. Society for Experimental Biology Seminar Series, 61; Cambridge University Press, Cambridge UK, pp. 159-176.

Veilleux, H.D., Donelson, J.M., Munday, P.L., 2018. Reproductive gene expression in a coral reef fish exposed to increasing temperature across generations. Conserv Physiol. 6, cox077. doi: 10.1093/conphys/cox077.

Vera, L. M., De Oliveira, C., López-Olmeda, J. F., Ramos, J., Mañanós, E, Madrid, J. A., SánchezVázquez, F. J. 2007. Seasonal and daily plasma melatonin rhythms and reproduction in Senegal sole kept under natural photoperiod and natural or controlled water temperature. J Pineal Res. 43: 50-55.

Verges, A., Mccosker, E., Mayer-Pinto, M., Coleman, M.A., Wernberg, T., Ainsworth, T., Steinberg, P.D., 2019. Tropicalisation of temperate reefs: Implications for ecosystem functions and management actions. Functional Ecology. 33, 1000-1013. doi: 10.1111/1365-2435.13310.

Vilchez, M.C., Morini, M., Penaranda, D.S., Gallego, V., Asturiano, J.F., Perez, L., 2017. Role of potassium and $\mathrm{pH}$ on the initiation of sperm motility in the European eel. Comp Biochem Physiol A Mol Integr Physiol. 203, 210-219. doi: 10.1016/j.cbpa.2016.09.024.

Villamizar, N., Ribas, L., Piferrer, F., Vera, L.M., Sánchez-Vázquez, F.J. 2012. Impact of daily thermocycles on hatching rhythms, larval performance and sex differentiation of zebrafish. PLoS One. 7(12):e52153.

Vincenzi, S., Mangel, M., Jesensek, D., Garza, J.C., Crivelli, A.J., 2017. Genetic and life-history consequences of extreme climate events. Proc Biol Sci. 284. 10.1098/rspb.2016.2118.

Wang, N., Teletchea, F., Kestemont, P., Milla, S., Fontaine, P., 2010. Photothermal control of the reproductive cycle in temperate fishes. Reviews in Aquaculture. 2, 209-222. doi: 10.1111/j.17535131.2010.01037.x.

Wang, S.Y., Lau, K., Lai, K.P., Zhang, J.W., Tse, A.C., Li, J.W., Tong, Y., Chan, T.F., Wong, C.K., Chiu, J.M., Au, D.W., Wong, A.S., Kong, R.Y., Wu, R.S., 2016. Hypoxia causes transgenerational impairments in reproduction of fish. Nat Commun. 7, 12114. doi: 10.1038/ncomms12114.

Watts, M., Pankhurst, N.W., King, H.R., 2004. Maintenance of Atlantic salmon (Salmo salar) at elevated temperature inhibits cytochrome P450 aromatase activity in isolated ovarian follicles. Gen Comp Endocrinol. 135, 381-390.

Wedekind, C., Küng, C. 2010. Shift of spawning season and effects of climate warming on developmental stages of a grayling (Salmonidae). Conserv Biol. 24(5):1418-23. doi: doi: 10.1111/j.1523-1739.2010.01534.x.

Welch, M.J., Munday, P.L., 2016. Contrasting effects of ocean acidification on reproduction in reef fishes. Coral Reefs. 35, 485-493. doi: 10.1007/s00338-015-1385-9.

West-Eberhard, M.J., 2005. Developmental plasticity and the origin of species differences. Proceedings of the National Academy of Sciences. 102, 6543-6549. doi: 10.1073/pnas.0501844102.

Westin, L., Nissling, A., 1991. Effects of salinity on spermatozoa motility, percentage of fertilized eggs and egg development of Baltic cod (Gadus morhua), and implications for cod stock fluctuations in the Baltic. Marine Biology. 108, 5-9. doi: 10.1007/bf01313465. 
Williams, C.R., Dittman, A.H., Mcelhany, P., Busch, D.S., Maher, M.T., Bammler, T.K., Macdonald, J.W., Gallagher, E.P., 2019. Elevated CO2 impairs olfactory-mediated neural and behavioral responses and gene expression in ocean-phase coho salmon (Oncorhynchus kisutch). Global Change Biology. 25, 963-977. doi: 10.1111/gcb.14532.

Wingfield, J.C., Sapolsky, R.M., 2003. Reproduction and resistance to stress: when and how. J Neuroendocrinol. 15, 711-724.

Wu, R., 2002. Hypoxia: from molecular responses to ecosystem responses. Mar Pollut Bull. 45, 35-45.

Wu, R.S.S., Zhou, B.S., Randall, D.J., Woo, N.Y.S., Lam, P.K.S., 2003. Aquatic hypoxia is an endocrine disruptor and impairs fish reproduction. Environmental Science \& Technology. 37, 1137-1141. doi: 10.1021/es0258327.

Yabuki, Y., Koide, T., Miyasaka, N., Wakisaka, N., Masuda, M., Ohkura, M., Nakai, J., Tsuge, K., Tsuchiya, S., Sugimoto, Y., Yoshihara, Y., 2016. Olfactory receptor for prostaglandin F2a mediates male fish courtship behavior. Nature Neuroscience. 19, 897. doi: 10.1038/nn.4314. https://www.nature.com/articles/nn.4314\#supplementary-information.

Yamaguchi, T., Yoshinaga, N., Yazawa, T., Gen, K., Kitano, T., 2010. Cortisol is involved in temperature-dependent sex determination in the Japanese flounder. Endocrinology. 151, 39003908. doi: 10.1210/en.2010-0228.

Yeganeh, S., Amiri, B.M., Alavi, S.M.H., 2008. Motility of Mugil cephalus L. spermatozoa in coelomic fluid, seminal fluid and saline media. Journal of Applied Ichthyology. 24, 517-518. doi: 10.1111/j.1439-0426.2008.01143.x.

Zachmann, A., Falcón, J., Knijff, S.C., Bolliet, V., Ali, M.A. 1992. Effects of photoperiod and temperature on rhythmic melatonin secretion from the pineal organ of the white sucker (Catostomus commersoni) in vitro. Gen Comp Endocrinol. 86: 26-33.

Zanuy, S., Carrillo, M., Ruiz, F., 1986. Delayed gametogenesis and spawning of sea bass (Dicentrarchus labrax L.) kept under different photoperiod and temperature regimes. Fish Physiol. Biochem. 2, 53-63.

Zheng, W., Stacey, N.E., 1997. A steroidal pheromone and spawning stimuli act via different neuroendocrine mechanisms to increase gonadotropin and milt volume in male goldfish Carassius auratus. General and Comparative Endocrinology. 105, 228-238.

Zhu, Y., Liu, D., Shaner, Z.C., Chen, S., Hong, W., Stellwag, E.J., 2015. Nuclear progestin receptor (pgr) knockouts in zebrafish demonstrate role for pgr in ovulation but not in rapid non-genomic steroid mediated meiosis resumption. Frontiers in endocrinology. 19;6:37. doi: 10.3389/fendo.2015.00037.

Zhu, Y., Rice, C.D., Pang, Y., Pace, M., Thomas, P., 2003. Cloning, expression, and characterization of a membrane progestin receptor and evidence it is an intermediary in meiotic maturation of fish oocytes. Proceedings of the National Academy of Sciences. 100, 2231-2236. doi: 10.1073/pnas.0336132100.

Zilli, L., Schiavone, R., Zonno, V., Storelli, C., Vilella, S., 2004. Adenosine triphosphate concentration and beta-D-glucuronidase activity as indicators of sea bass semen quality. Biol Reprod. 70, 16791684. doi: 10.1095/biolreprod.103.027177.

Zmora, N., Stubblefield, J., Zulperi, Z., Biran, J., Levavi-Sivan, B., Muñoz-Cueto, J.A., Zohar, Y. 2012. Differential and gonad stage-dependent roles of kisspeptin1 and kisspeptin2 in reproduction in the modern teleosts, morone species. Biol Reprod. 86(6): 177.

Zohar, Y., Muñoz-Cueto, J.A., Elizur, A., Kah, O., 2010. Neuroendocrinology of reproduction in teleost fish. General and Comparative Endocrinology. 165, 438-455. doi: 10.1016/j.ygcen.2009.04.017. 


\section{Abstract}

Anthropogenic emissions of carbon dioxide in the atmosphere have generated rapid variations in atmospheric composition which drives major climate changes. Climate change related effects include changes in physico-chemical proprieties of sea and freshwater, such as variations in water temperature, salinity, $\mathrm{pH} / \mathrm{PCO}_{2}$ and oxygen content, which can impact fish critical physiological functions including reproduction. In this context, the main aim of the present review is to discuss how climate change related effects (variation in water temperature and salinity, increases in duration and frequency of hypoxia events, water acidification) would impact reproduction by affecting the neuroendocrine axis (brain-pituitary-gonad axis).

Variations in temperature and photoperiod regimes are known to strongly affect sex differentiation and the timing and phenology of spawning period in several fish species. Temperature mainly acts at the level of gonad by interfering with steroidogenesis, (notably on gonadal aromatase activity) and gametogenesis. Temperature is also directly involved in the quality of released gametes and embryos development. Changes in salinity or water acidification are especially associated with reduction of sperm quality and reproductive output. Hypoxia events are able to interact with gonad steroidogenesis by acting on the steroids precursor cholesterol availability or directly on aromatase action, with an impact on the quality of gametes and reproductive success. Climate change related effects on water parameters likely influence also the reproductive behavior of fish. Although the precise mechanisms underlying the regulation of these effects are not always understood, in this review we discuss different hypothesis and propose future research perspectives.

\section{AUTHOR DECLARATION}

We wish to confirm that there are no known conflicts of interest associated with this publication and there has been no significant financial support for this work that could have influenced its outcome.

We confirm that the manuscript has been read and approved by all named authors and that there are no other persons who satisfied the criteria for authorship but are not listed. We further confirm that the order of authors listed in the manuscript has been approved by all of us. 
We confirm that we have given due consideration to the protection of intellectual property associated with this work and that there are no impediments to publication, including the timing of publication, with respect to intellectual property. In so doing we confirm that we have followed the regulations of our institutions concerning intellectual property.

We understand that the Corresponding Author is the sole contact for the Editorial process (including Editorial Manager and direct communications with the office). She is responsible for communicating with the other authors about progress, submissions of revisions and final approval of proofs. We confirm that we have provided a current, correct email address which is accessible by the Corresponding Author and which has been configured to accept email from (arianna.servili@ifremer.fr).

Signed by all authors as follows:

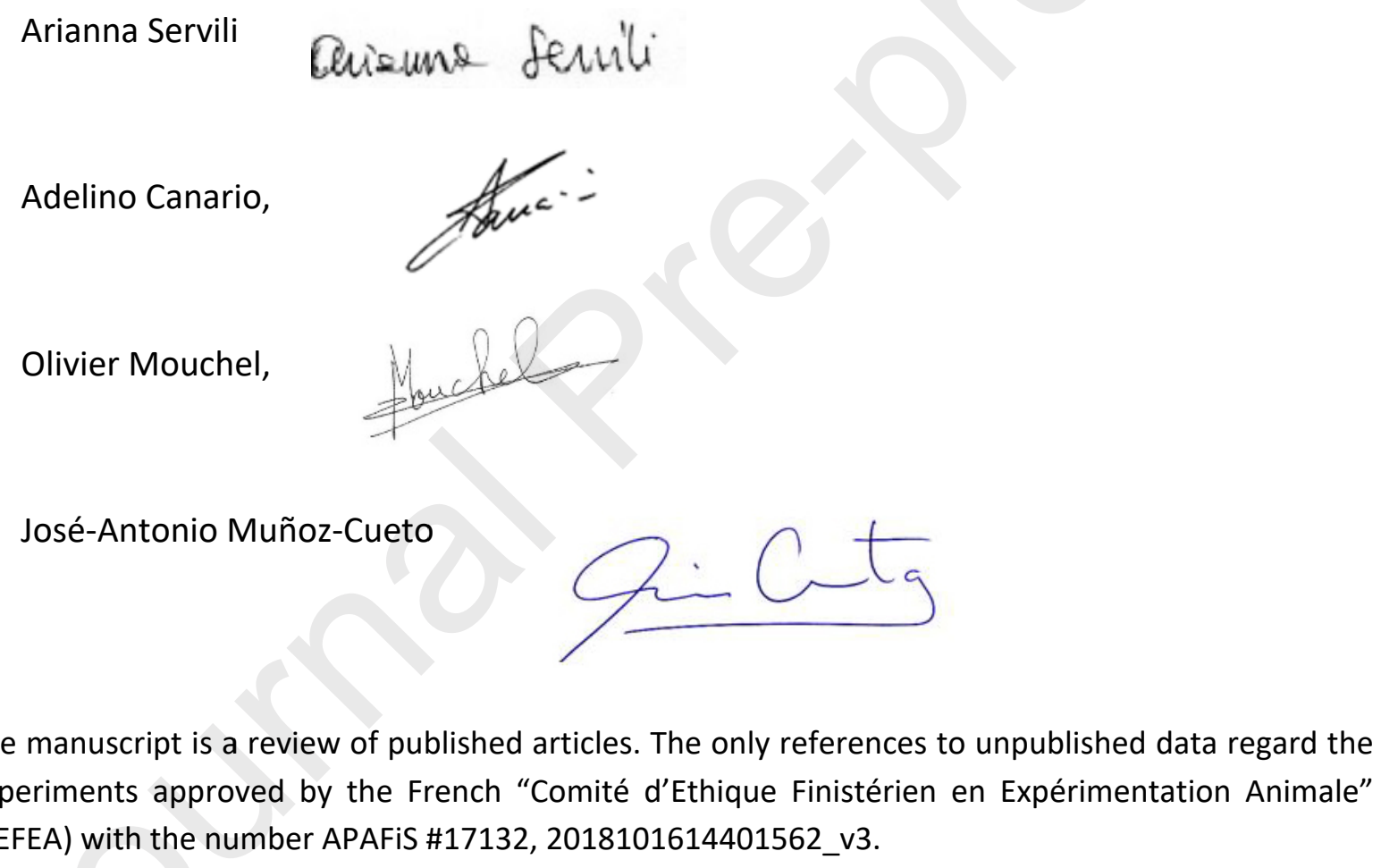

Figure captions

Figure 1. Example of good (A) and bad (B) quality of European sea bass eggs at morula stage produced and reared under present-day (A) and acidified (B) conditions. Note in $B$ the differences in transparency and morphology of the egg and the deformation of the blastodisk (arrow). Scale bar = $200 \mu \mathrm{m}$

Figure 2. Schematic representation of the main interactions of global change related environmental cues on brain-pituitary-gonad axis in fish will particular focus on the direct effects on gametes 
quality. GnRH, gonadotropin releasing hormone; $\mathbf{G n I H}$, gonadotropin inhibitory hormone; $5 \mathbf{H T}$, serotonin; GABA, aminobutyric acid; NPY, neuropeptide Y; Kiss, kisspeptin; LH, luteinizing hormone; FSH, follicle-stimulating hormone; $\mathbf{C H}$, cholesterol, P, progesterone, 17HP,17 $\alpha$-hydroxyprogesterone; $\mathbf{T}$, testosterone; aro, gonadal aromatase (cyp19a1a); $\mathbf{E}_{2}$, Estradiol; $11 \mathrm{KT}, 11$ ketotestosterone; 17,20ßP, 17,20ß-dihydroxy-4-pregnen-3-one; 20ß-S, 17,20,21-trihydroxy-4-pregnen-3-one, VTG, vitellogenin; $\mathbf{m P R} \boldsymbol{\alpha}$, membrane progestin receptor alpha; $\mathbf{n P R}$, nuclear progesterone receptor; TRPV, vanilloid transient receptor potential channels; PCNA, proliferating cell nuclear antigen; HSP70, heat shock protein 70. Question mark indicates a potential interaction that is not demonstrated yet. The drawings of brain, pituitary, gonad, liver and gametes are not represented in scale.

\section{Highlights}

- Changes in temperature, salinity, acidification and hypoxia impact reproductive behavior

- Sex differentiation is affected by temperature and thermocycles

- Environmental cues act on steroidogenesis/gametogenesis affecting gamete quality

- Global change related variations also affect spawning timing and phenology

- Transgenerational studies show examples of acclimation and adaptation

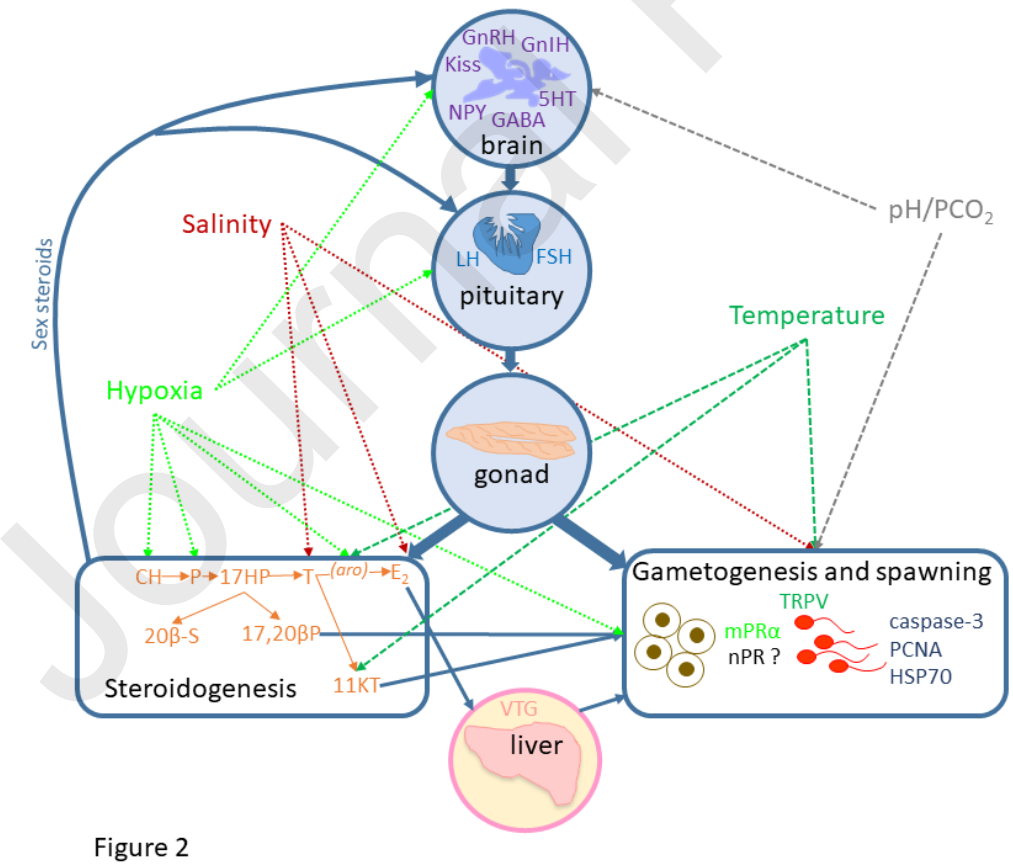




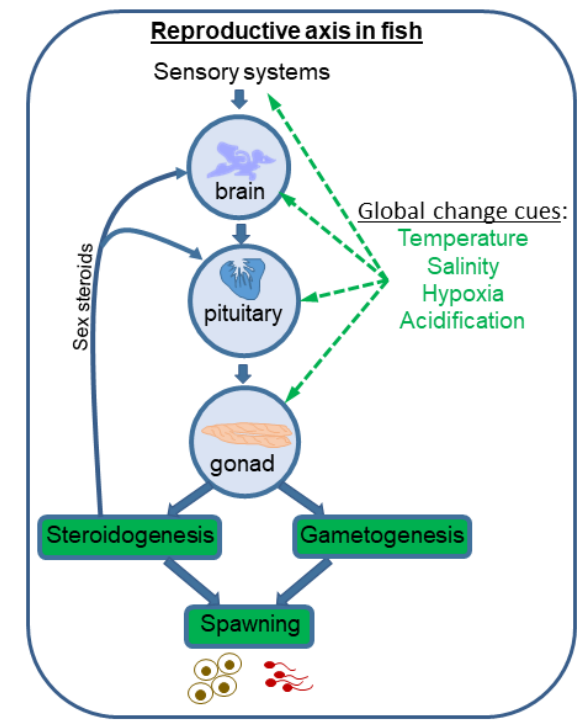

Graphical abstract 